\title{
High-resolution air quality simulation over Europe with the chemistry transport model CHIMERE
}

\author{
E. Terrenoire ${ }^{1}$, B. Bessagnet ${ }^{1}$, L. Rouil ${ }^{1}$, F. Tognet ${ }^{1}$, G. Pirovano ${ }^{2}$, L. Létinois ${ }^{1}$, M. Beauchamp ${ }^{1}$, A. Colette ${ }^{1}$, \\ P. Thunis ${ }^{3}$, M. Amann ${ }^{4}$, and L. Menut ${ }^{5}$ \\ ${ }^{1}$ INERIS, Parc Technologique Alata, BP 2, 60550 Verneuil-en-Halatte, France \\ ${ }^{2}$ RSE, Via Rubattino 54, 20134 Milan, Italy \\ ${ }^{3}$ JRC, Via Enrico Fermi 2749, 21027 Ispra, Italy \\ ${ }^{4}$ IIASA, Schlossplatz 1, 2361 Laxenburg, Austria \\ ${ }^{5}$ IPSL-LMD, UMR8539, Ecole Polytechnique, Palaiseau, France
}

Correspondence to: E. Terrenoire (eterrenoire@yahoo.fr)

Received: 28 June 2013 - Published in Geosci. Model Dev. Discuss.: 2 August 2013

Revised: 16 October 2014 - Accepted: 21 November 2014 - Published: 14 January 2015

\begin{abstract}
A modified version of CHIMERE 2009, including new methodologies in emissions modelling and an urban correction, is used to perform a simulation at high resolution $\left(0.125^{\circ} \times 0.0625^{\circ}\right)$ over Europe for the year 2009. The model reproduces the temporal variability of $\mathrm{NO}_{2}, \mathrm{O}_{3}, \mathrm{PM}_{10}$, $\mathrm{PM}_{2.5}$ better at rural (RB) than urban (UB) background stations, with yearly correlation values for the different pollutants ranging between 0.62 and 0.77 at $\mathrm{RB}$ sites and between 0.52 and 0.73 at UB sites. Also, the fractional biases (FBs) show that the model performs slightly better at RB sites than at $\mathrm{UB}$ sites for $\mathrm{NO}_{2}(\mathrm{RB}=-33.9 \%, \mathrm{UB}=-53.6 \%)$, $\mathrm{O}_{3}(\mathrm{RB}=20.1 \%, \mathrm{UB}=25.2 \%)$ and $\mathrm{PM}_{10}(\mathrm{RB}=-5.50 \%$, $\mathrm{UB}=-20.1 \%)$. The difficulties for the model in reproducing $\mathrm{NO}_{2}$ concentrations can be attributed to the general underestimation of $\mathrm{NO}_{\mathrm{x}}$ emissions as well as to the adopted horizontal resolution, which represents only partially the spatial gradient of the emissions over medium-size and small cities. The overestimation of $\mathrm{O}_{3}$ by the model is related to the $\mathrm{NO}_{2}$ underestimation and the overestimated $\mathrm{O}_{3}$ concentrations of the lateral boundary conditions. At UB sites, CHIMERE reproduces $\mathrm{PM}_{2.5}$ better than $\mathrm{PM}_{10}$. This is primarily the result of an underestimation of coarse particulate matter (PM) associated with uncertainties in secondary organic aerosol (SOA) chemistry and its precursor emissions (Po valley and Mediterranean basin), dust (south of Spain) and sea salt (western Europe). The results suggest that future work should focus on the development of national bottomup emission inventories including a better account for semi-
\end{abstract}

volatile organic compounds and their conversion to SOA, the improvement of the CHIMERE urban parameterization, the introduction into CHIMERE of the coarse nitrate chemistry and an advanced parameterization accounting for windblown dust emissions.

\section{Introduction}

Regional chemistry transport models (CTMs) are powerful tools widely used to assess and investigate air quality issues. The application field of CTMs is broad: understanding the atmospheric physico-chemical processes (Bessagnet et al., 2010; Hodzic et al., 2010; Jiménez-Guerrero et al., 2011), assessment of emission control scenarios (Coll et al., 2009; Kiesewetter et al., 2014), past and future regional air pollution trends (Colette et al., 2011), chemical weather forecast cooperation (Balk et al., 2011; Kukkonen et al., 2011; Copernicus (http://www.copernicus.eu/)) and natural hazard emergency response (Colette et al., 2011; Matthias et al., 2012). A review of the major air quality modelling forecast systems operating in Europe is given by Menut and Bessagnet (2010).

CTMs were used initially to simulate gas phase tropospheric pollutant concentrations within the lower troposphere; a coarse horizontal resolution was sufficient to achieve this objective. During the past decade, air quality legislation has focused more and more on particulate matter (PM) concentrations and CTMs have been equipped with 
E. Terrenoire et al.: High-resolution air quality simulation over Europe

aerosol modules. High PM concentrations are usually observed in urban areas (EEA, 2012), leading to a need for CTM applications at urban scale. A large number of studies highlight the need to perform simulations at high resolution in order to assess the urban air pollutant concentration patterns, especially for PM compounds (Queen and Zhang, 2008; Stroud et al., 2011; Wolke et al., 2012; Fountoukis et al., 2013).

A list of long-term European model evaluation studies that took place during the past decade can be found in Pay et al. (2012a). However, the simulations performed in these studies adopted a coarse $\left(0.25\right.$ to $\left.0.5^{\circ}\right)$ horizontal resolution (Tarrason et al., 2006; Matthias, 2008; Stern et al., 2008; Kim et al., 2011; Sollazo et al., 2012; Pay et al., 2012a; Pirovano et al., 2012; Zhang et al., 2013) and the evaluation was generally done using a limited set of measurement stations. Examples of model validation can also be found for higher resolution applications $\left(0.1^{\circ} \times 0.1^{\circ}\right)$ but over limited domains, covering an urban area or a country (Hodzic et al., 2005; Tombette and Sportisse, 2007; Flaounas et al., 2009; Chemel et al., 2010; Pay et al., 2012b). Therefore, there is a clear need for evaluating high-resolution simulations $\left(<0.1^{\circ} \times 0.1^{\circ}\right)$ performed over large domains, such as continental areas.

To fill this gap, a high-resolution air quality simulation was performed over most of Europe and evaluated for the year 2009 using the CHIMERE model (Menut et al., 2013). For this study, the CHIMERE model was improved in order to simulate air quality at the urban scale. The evaluation process was conducted over a comprehensive spatial and temporal data set in order to effectively quantify the model accuracy. The aims of the study are threefold: (i) to get an accurate picture of air quality at the urban scale using air quality modelling; (ii) to test an original set of emissions and an urban meteorological correction; (iii) to evaluate comprehensively the simulation using the largest set of monitoring stations available over Europe.

The analysis was performed for sulfur dioxide $\left(\mathrm{SO}_{2}\right)$, nitrogen dioxide $\left(\mathrm{NO}_{2}\right)$, ozone $\left(\mathrm{O}_{3}\right), \mathrm{PM}_{10}$ (particulate matter with an aerodynamic diameter $\leq 10 \mu \mathrm{m}$ ), $\mathrm{PM}_{2.5}$ (particulate matter with an aerodynamic diameter $\leq 2.5 \mu \mathrm{m}$ ) and particulate matter (PM) compounds such as sulfate, nitrate, total nitrate (nitric acid + nitrate), ammonium and total ammonia (ammonia + ammonium).

The paper is organized as follows. Section 2 is devoted to the description of CHIMERE and the methodology used to prepare the anthropogenic emissions as well as the set of observations selected for the evaluation. Section 3 describes and analyses comprehensively the ability of the model to reproduce the concentrations of the different selected pollutants. Finally, Sect. 4 summarizes the main findings raised by the study and gives suggestions for future work related to high-resolution regional modelling.

\section{Methods}

\subsection{Model description}

CHIMERE is a regional CTM that has undergone several extensive evaluations (Bessagnet et al., 2010; Vautard et al., 2007a; Van Loon et al., 2007). It calculates the concentrations of the main chemical species $\left(\mathrm{SO}_{2}, \mathrm{NO}_{2}, \mathrm{O}_{3}, \mathrm{PM}_{10}\right.$, $\mathrm{PM}_{2.5}$ ) that are involved in the physico-chemistry of the lower troposphere. CHIMERE has been described in detail in several papers: Schmidt et al. (2001) for the dynamics and the gas phase module; Bessagnet et al. (2009) for the aerosol module and Vautard et al. (2005, 2007b) for further model developments including the introduction of a mineral dust emission module and a convection scheme into CHIMERE.

The version used in this study is CHIMERE 2009 with specific modifications described in the following paragraphs of this section. The aerosol model species are the primary particle material (PPM), secondary inorganic aerosol (SIA; sulfate, nitrate and ammonium) based on the ISORROPIA thermodynamic equilibrium model (Nenes et al., 1998), secondary organic aerosol (SOA, whose formation is represented according to a single-step oxidation of the relevant anthropogenic and biogenic precursors), sea salt and dust (nonAfrican mineral dust is not included). The particles' size distribution ranges from $39 \mathrm{~nm}$ to $10 \mu \mathrm{m}$ and the particles are distributed into eight bins $(0.039,0.078,0.156,0.312,0.625$, $1.25,2.5,5$ and $10 \mu \mathrm{m})$. Vertically, the domain is divided in eight hybrid-sigma layers from the ground to $500 \mathrm{hPa}$. Gas phase tropospheric chemistry is represented using the reduced MELCHIOR chemical mechanism (120 reactions and 44 gaseous species) and the dry and wet depositions are taken into account. For the study, a nested domain $(328 \times 416$ grid boxes) that covers most of Europe from $10.43750^{\circ} \mathrm{W}$ to $30.43750^{\circ} \mathrm{E}$ in longitude and 35.90620 to $61.83375^{\circ} \mathrm{N}$ in latitude with a horizontal resolution of $0.125^{\circ} \times 0.0625^{\circ}$ $(8 \mathrm{~km} \times 8 \mathrm{~km})$ is designed (Fig. 1). Boundary conditions for the mother domain were derived from monthly mean climatology based on the Laboratoire de Météorologie Dynamique Zoom - Interaction avec la Chimie et les Aérosols (LMDz4-INCA3) model for gaseous species (Hauglustaine et al., 2004) and the Goddard Chemistry Aerosol Radiation and Transport (GOCART) model for aerosols (Ginoux et al., 2001). A complete and high-resolution set of both biogenic and anthropogenic emissions are needed in order to perform the CHIMERE computations. Emissions of six biogenic CHIMERE species (isoprene, $\alpha$-pinene, $\beta$-pinene, limonene, ocimene and NO) were calculated using the Model of Emission of Gases and Aerosols from Nature (MEGAN v.2.04, Guenther et al., 2006). Wildfire emissions are also taken into account and issued from the Global Fire Emissions Database version 3 (Kaiser et al., 2012). Modelled concentrations for comparison with observations are extracted from the lowest vertical level, which extends from the ground to about 


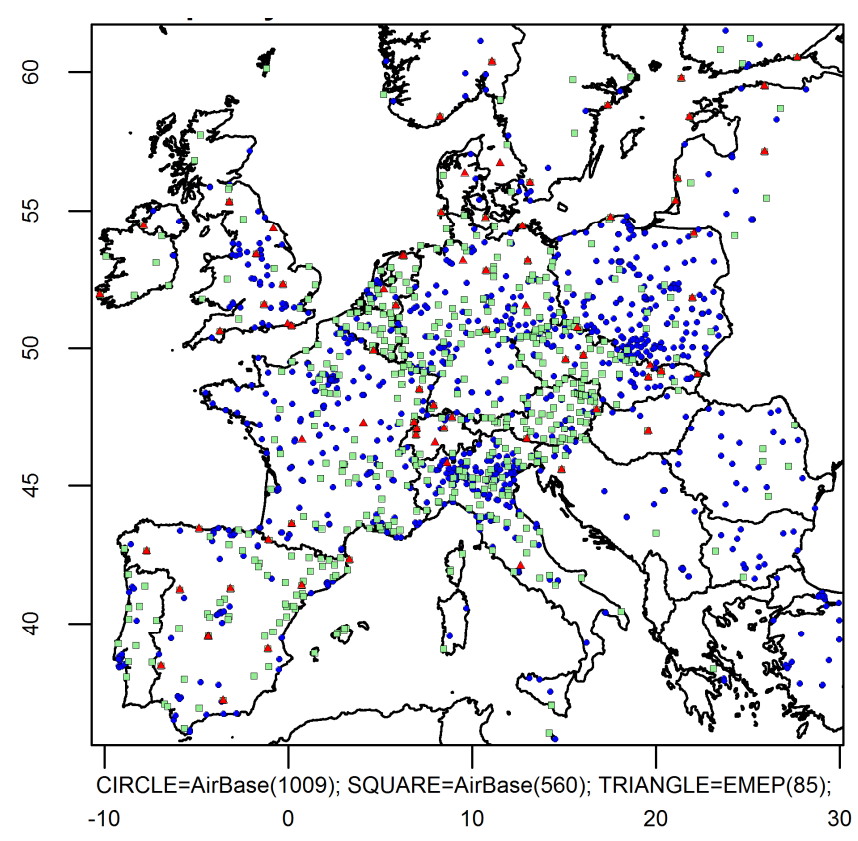

Figure 1. AirBase rural background (RB; green squares), AirBase urban background (UB; blue dots) and EMEP stations (red triangles) used for the model performance evaluation.

$20 \mathrm{~m}$. A detailed description of CHIMERE can be found in Menut et al. (2013).

\subsection{Meteorology}

Meteorological data needed by CHIMERE are derived from the fields of the Integrated Forecast System (IFS) runs at the European Centre for Medium-range Weather Forecasts (ECMWF). The choice of feeding CHIMERE directly with the IFS data stems from the results of a sensitivity analysis where the performance of the Weather Research and Forecasting (WRF) limited area model and the IFS was evaluated against observations (not shown here). The analysis shows evidence of a systematic overestimation of the wind speed by WRF, a feature confirmed by several other studies (Mass and Ovens, 2011; Jimenez and Dudhia, 2012; Vautard et al., 2012). Another reason for the direct use of ECMWF-IFS fields is that it avoids an ad hoc meteorological numerical weather calculation (e.g. WRF), thus reducing the computational cost. For more details about the comparison between ECMWF-IFS and WRF performance, the reader is referred to Miglietta et al. (2012).

IFS adopts a $0.25^{\circ}$ horizontal grid spacing from surface up to $0.1 \mathrm{hPa}$ (91 levels in total). It provides standard meteorological variables (temperature, wind components, specific humidity, pressure, sensible and latent heat fluxes) that need to be vertically and horizontally interpolated on the CHIMERE grid (eight levels). Some additional variables are also diagnosed by CHIMERE from the available fields, such as friction velocity and vertical wind speed, which are used to complete the description of vertical transport and turbulent diffusion.

However, the main limitation of such data is that the IFS regional scale data cannot sufficiently represent the urban scale meteorology observed in the urban boundary layer. This is crucial, as the urban canopy affects the wind circulation and the urban energy balance (Sarrat et al., 2006), which directly impact the transport and the vertical diffusion of primary pollutants over cities (e.g. $\mathrm{O}_{3}, \mathrm{NO}_{2}$ and $\mathrm{PM}$ ). Usually, operational meteorological observations are performed outside urban areas (e.g. airport) for representativeness reasons. Several studies have shown large differences between urban and rural winds (Fisher et al., 2006), showing a wind speed ratio (rural/urban) of up to 2. Another study, focused on Lisbon (Portugal), showed that modelled wind speed ratio inside the canopy and at the top of the urban sub-layer was within the range 0.1 to 0.6 (Solazzo et al., 2010).

The vertical diffusion (diffusion coefficient, $\mathrm{Kz}$ ) is used in CHIMERE to compute the vertical turbulent mixing in the boundary layer following the parameterization of Troen and Mahrt (1986). In order to integrate the influence of the urban canopy on meteorology, the wind speed, as well as the $\mathrm{Kz}$, is modified within the CHIMERE version used for this study. The wind speed and the $\mathrm{Kz}$ are divided by a factor of 2 over the urban areas (urban cells) in the lowest CHIMERE layer as described in Bessagnet et al. (2012). The grid cells' land use classification was derived from the GlobCover (Bicheron et al., 2008) land cover database covering the period December 2004-June 2006.

In order to estimate the potential impact of the urban correction, a sensitivity test was performed for January 2009.

Figure 2 shows the results of the simulation without the urban correction for $\mathrm{NO}_{2}, \mathrm{O}_{3}, \mathrm{PM}_{10}$ and $\mathrm{PM}_{2.5}$. Concentrations are normalized by the values obtained in the actual base case that include the urban correction. A rather large impact over all major European cities is observed for the four pollutants. For $\mathrm{NO}_{2}$, a decrease in concentrations ranging from a few \% (suburban areas) up to $45 \%$ (e.g. Paris, London, Lisbon and Glasgow) is observed when the urban correction is not applied. Conversely an increase of $\mathrm{O}_{3}$ concentration is observed over both the large cities (10 to $120 \%$ in the city centre) and medium-size cities (10 to $30 \%$ ), essentially due to a decrease of $\mathrm{NO}_{2}$ titration. Likewise $\mathrm{NO}_{2}$, the concentrations of both $\mathrm{PM}_{10}$ and $\mathrm{PM}_{2.5}$ decrease from a few $\%$ to a maximum of $43 \%$ in cities such as Paris, London and Katowice in the south of Poland. Finally, the yearly box-whisker plots time series (Figs. S1 to S4 in the Supplement) show that the median of the modelled concentrations increases for $\mathrm{NO}_{2}$ (0.6 ppb), $\mathrm{PM}_{10}\left(0.8 \mu \mathrm{g} \mathrm{m}^{-3}\right)$ and $\mathrm{PM}_{2.5}\left(0.4 \mu \mathrm{g} \mathrm{m}^{-3}\right)$ at urban background (UB) stations when using the urban correction while it decreases for $\mathrm{O}_{3}(0.8 \mathrm{ppb})$. At UB stations, on average, the impact of the urban correction is positive (reducing the bias) but small. 

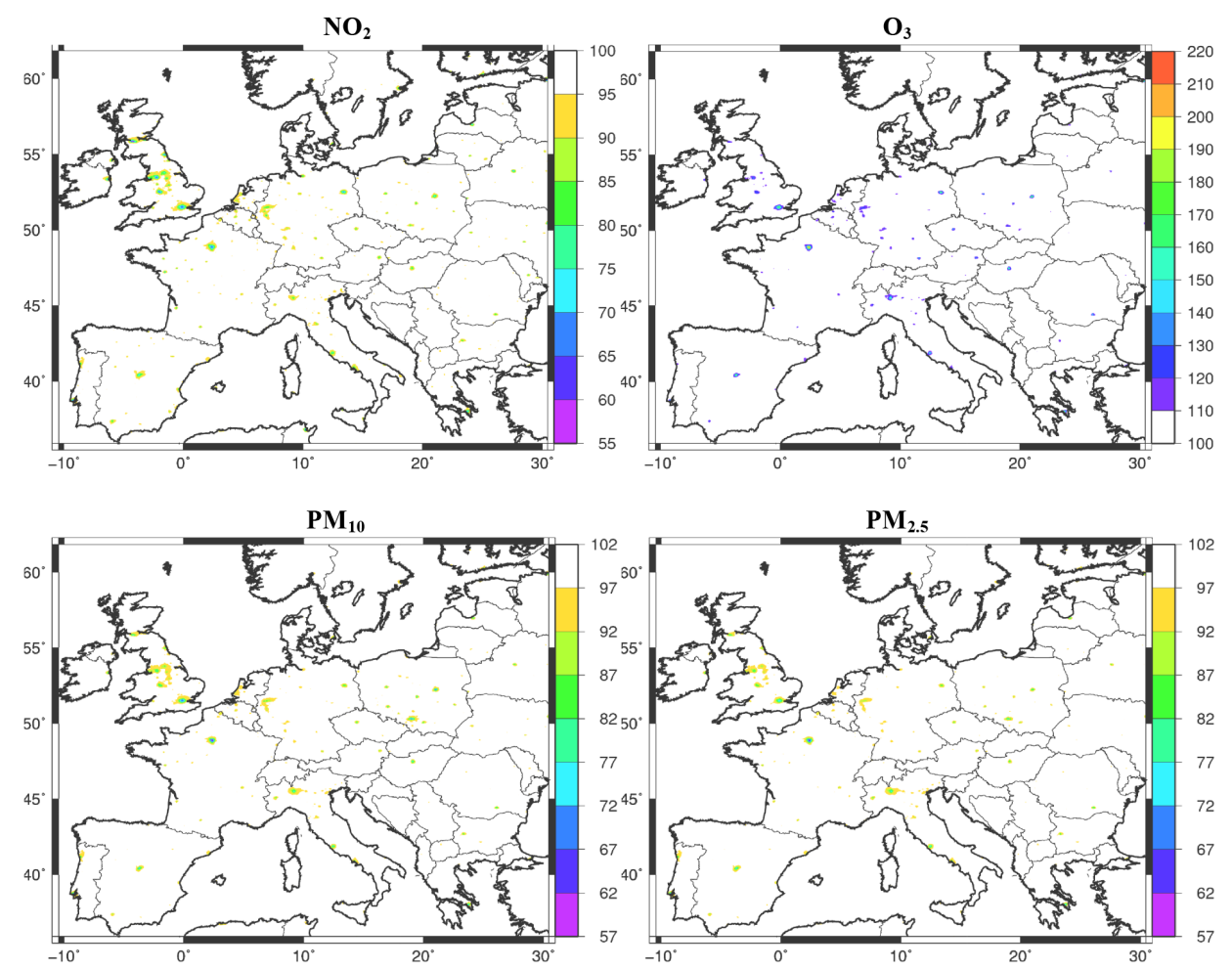

Figure 2. Concentration from the simulation without the urban correction normalized by the simulation including the urban correction (in \%) for $\mathrm{NO}_{2}, \mathrm{O}_{3}, \mathrm{PM}_{10}$ and $\mathrm{PM}_{2.5}$.

\subsection{Anthropogenic emissions}

Five main steps can be identified in the anthropogenic emission pre-processing: (1) the horizontal and vertical spatial regridding of the raw emissions to comply with the CHIMERE grid, (2) the temporal disaggregation, (3) the chemical speciation, (4) the hourly disaggregation and (5) the surface flux calculation within CHIMERE.

The anthropogenic emissions CHIMERE pre-processor transforms raw yearly anthropogenic emissions (t/year/cells) into a CHIMERE compliant spatialized emissions data set available for PPM, NO, $\mathrm{NO}_{2}, \mathrm{CO}, \mathrm{SO}_{2}, \mathrm{CH}_{4}$ and the 10 following non-methane volatile organic compounds (NMVOCs): Ethane, n-butane, ethene, propene, oxylene, formaldehyde, acetaldehyde, methyl, ethyl-ketone and ethanol.

\subsubsection{Spatial regridding of anthropogenic emissions}

The raw emission data of the main air pollutants (NMVOC, $\mathrm{NO}_{\mathrm{x}}, \mathrm{CO}, \mathrm{SO}_{2}, \mathrm{NH}_{3}, \mathrm{PPM}$ ) are provided per activity sector, according to level 1 of the Selected Nomenclature for Air Pollution (SNAP). They come from three different databases:

- the Netherlands Organisation for Applied Scientific Research (TNO) emission inventory at $0.125^{\circ} \times 0.0625^{\circ}$ for 2007 from the Modelling Atmospheric Composition
Change (MACC) project (Kuenen et al., 2011; Denier van der Gon et al., 2010),

- the European Monitoring and Evaluation Programme (EMEP) $0.5^{\circ} \times 0.5^{\circ}$ emission inventory for 2009 (Vestreng et al., 2007),

- the emission data set available in the Greenhouse Gas and Air Pollution Interactions and Synergies (GAINS) database (Amann et al., 2011).

The large point sources from the fine-scale TNO-MACC emission data for 2007 were added to surface emissions in order to deal with only gridded emissions.

The spatialization of the anthropogenic emissions depends on the SNAP sector. The TNO-MACC emissions were used as a proxy variable to regrid EMEP $0.5^{\circ} \times 0.5^{\circ}$ emission data (Kuenen et al., 2011) for the SNAP activity sectors 3, 7, 8, 9 and 10. For SNAP sectors 1,4 , 5 and 6 , emissions were distributed over artificial land use corresponding to the European Pollutant Emission Register (EPER) industries (eea.europa.eu/data-and-maps/ data/eper-the-european-pollutant-emission-register-4). For $\mathrm{PM}_{2.5}$, the GAINS national emissions totals were considered more reliable (Z. Klimont, personal communication, 2012) and used for the following countries: Czech Republic, Bosnia and Herzegovina, Belgium, Belarus, Spain, France, Croatia, Ireland, Lithuania, Luxembourg, Moldova, Macedonia, 
Table 1. Vertical emissions profiles (\%) for each SNAP category.

\begin{tabular}{lrrrrrrr}
\hline Injection height $(\mathrm{m})$ & 20 & 92 & 184 & 324 & 522 & 781 & 1106 \\
\hline SNAP 1 & 0 & 0 & 0.25 & 51 & 45.3 & 3.25 & 0.2 \\
SNAP 2 & 100 & 0 & 0 & 0 & 0 & 0 & 0 \\
SNAP 3 & 6 & 16 & 75 & 3 & 0 & 0 & 0 \\
SNAP 4 & 5 & 15 & 70 & 10 & 0 & 0 & 0 \\
SNAP 5 & 2 & 8 & 60 & 30 & 0 & 0 & 0 \\
SNAP 6 & 100 & 0 & 0 & 0 & 0 & 0 & 0 \\
SNAP 7 & 100 & 0 & 0 & 0 & 0 & 0 & 0 \\
SNAP 8 & 100 & 0 & 0 & 0 & 0 & 0 & 0 \\
SNAP 9 & 0 & 0 & 41 & 57 & 2 & 0 & 0 \\
SNAP 10 & 100 & 0 & 0 & 0 & 0 & 0 & 0 \\
SNAP 11 & 100 & 0 & 0 & 0 & 0 & 0 & 0 \\
& & & & & & &
\end{tabular}

Netherlands, Serbia and Montenegro and Turkey. Moreover, additional factors were applied on Polish regions ( $x 4$ or $x 8$ ) to compensate for the lack of $\mathrm{PM}_{2.5}$ emissions due to the domestic heating activity in the available inventory. Finally, emissions from SNAP 2 were disaggregated according to population density. The goal of this approach is to better capture the spatial variability of the SNAP 2 sources. The population data were provided by the Joint Research Centre (JRC) over a regular grid at $0.083^{\circ} \times 0.083^{\circ}$ horizontal resolution. For the elaboration of the SNAP 2 emissions, a distinction is made between gaseous and PPM species to better reallocate the anthropogenic biomass burning emissions (SNAP 2) over the rural areas. According to the French National Spatialised Emission Inventory (INS), (Ministère de l'Ecologie et du Développement Durable, 2009), available at municipality level and derived using the bottom-up approach, there is clear evidence that $\mathrm{PPM}_{2.5}$ (PPM with an aerodynamic diameter $\leq 2.5 \mu \mathrm{m}$ ) emissions per inhabitant sharply decrease when the population density increases (Fig. 3). This is due to the increase of the relative contribution of wood burning in the fuel mixture moving from urban centres to rural areas (e.g. due to an increase in domestic fireplaces). This effect is noticeable only for $\mathrm{PPM}_{2.5}$, because biomass burning sources contribute to a very large fraction of PM emissions in SNAP2, while they have less influence than other fuels on gas phase pollutants (INS, Ministère de l'Ecologie et du Développement Durable, 2004).

The vertical repartition of the emissions into the different levels of the CTM is known to be of great importance (Bieser et al., 2011). It was calculated for each SNAP sector following the calculation of Bieser et al. (2011) (Table 1). A new layer $(0-20 \mathrm{~m})$ was added to the current implementation compared to the original EMEP configuration. For SNAP 2, $6,7,8$ and 10 all the emissions are released into the first level of the model.

As an illustration, Fig. 4 shows the spatial distribution of the total annual $\mathrm{PPM}_{2.5}$ emissions from SNAP 2 derived from the hybrid emission inventory used for this study. Compared to the original method, SNAP 2 emissions around the medium-size and large cities increase when the population proxy is used. This is because when the Land Use (LU) proxy

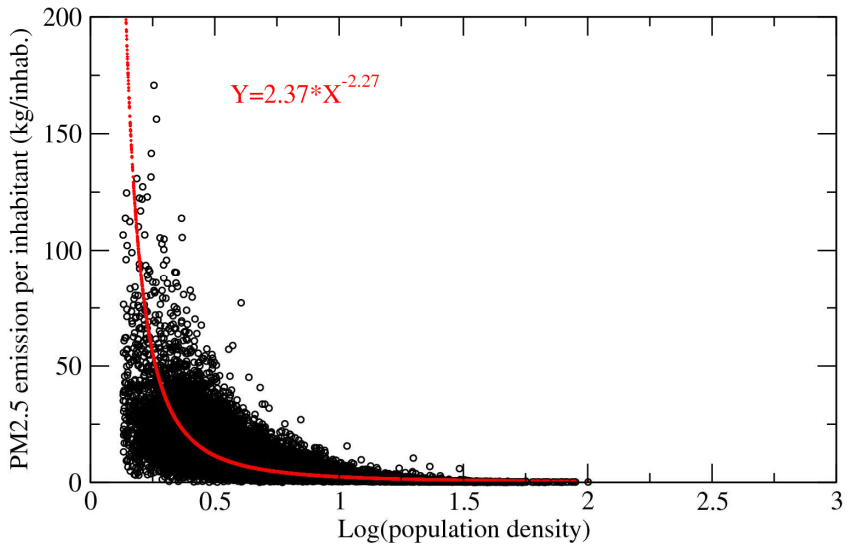

Figure 3. Evolution of $\mathrm{PPM}_{2.5}$ residential emissions per inhabitant $(\mathrm{kg} / \mathrm{inh}$ ab/year) as a function of population density (source: French National Emission Inventory). The red curve is the corresponding logarithmic regression used in the CHIMERE emission pre-processor.

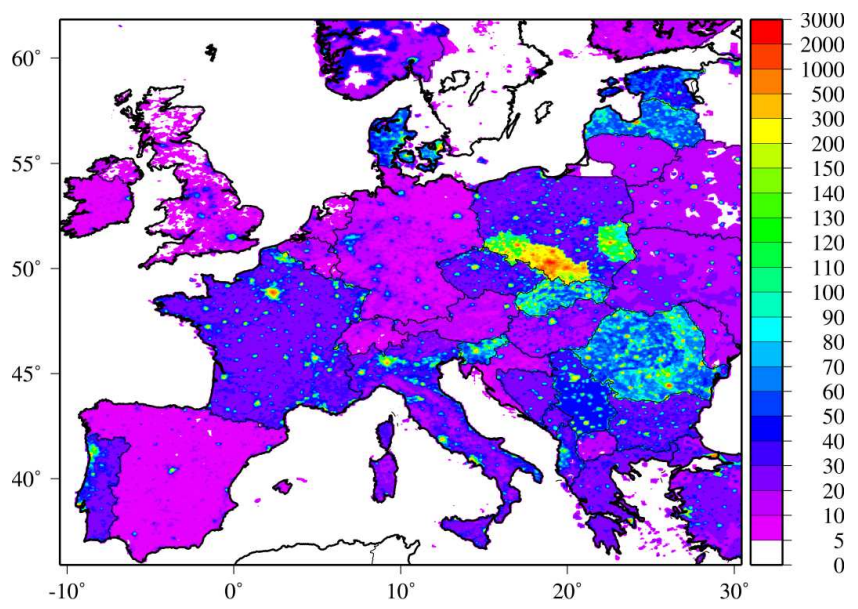

Figure 4. Total annual primary particle material emission with aerodynamic diameter $\leq 2.5 \mu \mathrm{m}$ from SNAP 2 for the year 2009 $\left(\mathrm{g} \mathrm{km}^{-2}\right)$.

is used, emissions from each type of LU cell have the same weight, thus giving rise to a flatter distribution than using population density. Considering for example an EMEP cell $\left(0.5^{\circ} \times 0.5^{\circ}\right)$ including a big city as well as a small town, emissions are modulated in the same way over urban cells of both areas if the LU approach is followed, whereas most of the emissions are allocated just in the big city if population is used.

\subsubsection{Emission temporal modulation}

Time disaggregation was done on the basis of the Generation and Evaluation of Emission (GENEMIS) project data using monthly, daily and hourly coefficients depending on the activity sector (Society et al., 1994). 
However, for SNAP 2, a new temporal profile derived according to the degree day concept is used. The degree day is an indicator used as a proxy variable to express the daily energy demand for heating (Verbai et al., 2014; Quayle and Diaz, 1980). The degree day for a day " $j$ " is defined as:

$D_{j}=\left\{\begin{array}{l}20-\bar{T} \text { when } 20-\bar{T}>0 \\ 0 \quad \text { when } 20-\bar{T} \leq 0\end{array}\right.$

where $\bar{T}$ is the daily mean $2 \mathrm{~m}$ temperature. Therefore, a first guess daily modulation factor could be defined as:

$F_{D}=\frac{D_{j}}{\bar{D}} \quad \bar{D}=\frac{1}{N} \sum_{j=1}^{N} D_{j}$,

where $N=365$ days.

Considering that SNAP 2 emissions are not only related to the air temperature (e.g. emissions due to production of hot tap water), a second term is introduced in the formula by means of a constant offset $C$. To better assess the influence of this offset, $C$ can be expressed as a fraction of $\bar{D}$ (degree day annual average).

Considering:

$C=A \cdot \bar{D}$,

where $A$ is defined by user ( $A=0.1$ for this application), we can express

$D_{j}^{\prime}=D_{j}+A \cdot \bar{D}$

and

$$
\begin{aligned}
\bar{D}_{j}^{\prime}= & \frac{1}{N} \sum_{j=1}^{N} D_{j}^{\prime}=\frac{1}{N} \sum_{j=1}^{N}\left(D_{j}+A \cdot \bar{D}\right)_{j} \\
& =\bar{D}+A \cdot \bar{D}=(1+A) \cdot \bar{D} .
\end{aligned}
$$

The daily modulation factor $\left(F_{j}^{\prime}\right)$ is therefore defined as:

$F_{j}^{\prime}=\frac{D_{j}^{\prime}}{\bar{D}_{j}^{\prime}}$.

Note that $F_{j}^{\prime}$ is mass conservative over the year and replaces the original monthly and daily modulation factors. The choice of $A$ is left to the user to express the relative weight of hot water production with respect to heating. For this application, we set $A=0.1$ in order to replicate as much as possible the original CHIMERE temporal profiles during the warmer season.

As an illustration, Fig. 5 shows the 2009 daily modulation factors applied to the SNAP 2 emissions at three locations that are both geographically and climatically different: Katowice (Poland), Paris (France) and Madrid (Spain). The highest factors for the three locations occur during the winter period and the lowest ones during the summer, as expected.

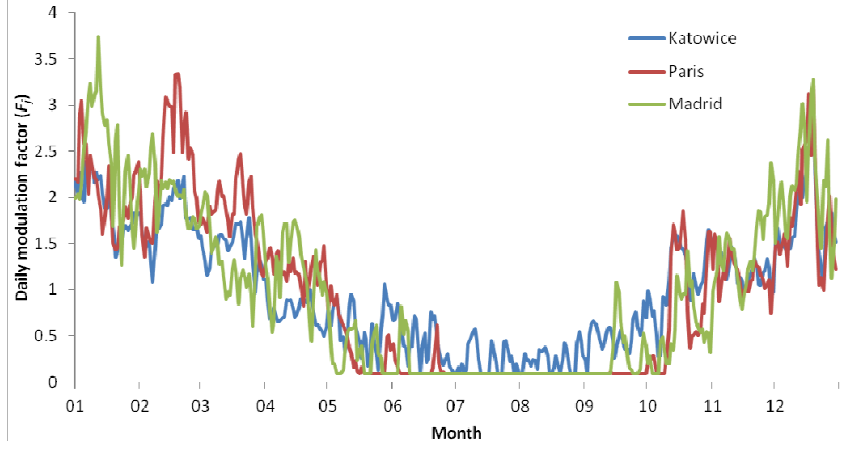

Figure 5. Daily modulation factors $\left(F_{j}\right)$ applied for the SNAP 2 emissions over the city of Katowice, Paris and Madrid for the year 2009.

This means, for example, that during the cold periods the emission from SNAP 2 can be up to three times more intense (e.g. beginning of January for Madrid or end of February for Paris) than during the spring or the autumn periods. It is interesting to note that in Katowice during the beginning of the year the factors are relatively lower than at the two other locations, meaning that over this period the difference between the daily mean and the annual mean temperatures is lower in Katowice than at the two other locations. This does not mean that temperature in Katowice during January was higher than Madrid and Paris, but simply that the latter ones experience a higher variability than Katowice between January and the summer season. Indeed, it is worth noting that in Katowice the modulation factor during the summer is often greater than 0.1 , indicating that in several cases, the daily temperature in Katowice is lower than $20^{\circ} \mathrm{C}$. Conversely, at the end of the year, all locations experienced a cold outbreak of the same intensity relative to their local annual mean temperature.

\subsubsection{Chemical speciation}

Annual $\mathrm{NO}_{\mathrm{x}}$ emissions were speciated into $\mathrm{NO}, \mathrm{NO}_{2}$ and $\mathrm{HNO}_{2}$ using the coefficients recommended by the International Institute for Applied Systems Analysis (IIASA) (Z. Klimont, personal communication, 2012, Table 2). For NMVOC, a speciation was performed over 32 NMVOC National Acid Precipitations Assessment Program (NAPAP) classes (Middleton et al., 1990). Real NMVOC species were aggregated and assigned to the model species following Middleton et al. (1990).

\subsection{Observation data}

Observed data come from two different databases. The first is AirBase (http://acm.eionet.europa.eu/databases), gathering regulatory data reported by Member States according to the air quality directive. The second is related to the EMEP network (http://www.emep.int/). Only stations below $750 \mathrm{~m}$ in altitude with at least $75 \%$ data capture over the year were 
Table 2. $\mathrm{NO}_{\mathrm{x}}$ speciation (\%) used in CHIMERE for each SNAP category.

\begin{tabular}{lrrrrrrrrrr}
\hline & SNAP1 & SNAP 2 & SNAP3 & SNAP4 & SNAP5 & SNAP6 & SNAP7 & SNAP8 & SNAP9 & SNAP 11 \\
\hline $\mathrm{NO}$ & 95.0 & 95.0 & 95.0 & 95.0 & 95.0 & 95.0 & 83.5 & 90.0 & 95.0 & 95.0 \\
$\mathrm{NO}_{2}$ & 4.50 & 4.50 & 4.50 & 4.50 & 4.50 & 4.50 & 15.0 & 9.20 & 4.50 & 4.50 \\
$\mathrm{HNO}_{2}$ & 0.50 & 0.50 & 0.50 & 0.50 & 0.50 & 0.50 & 1.50 & 0.80 & 0.50 & 0.50 \\
\hline
\end{tabular}

selected as we wanted to avoid stations with complex terrain. Figure 1 displays the spatial distribution of the AirBase (green squares for rural background (RB) and blue dots for UB) and EMEP network stations (red triangles) used for the evaluation. The spatial distribution of the stations is homogeneous over the populated region of western Europe, while several gaps are seen in Eastern Europe and in the Balkan countries. A total of 1009 UB AirBase, 560 RB AirBase and 85 EMEP stations are used for the evaluation. However, fewer stations are available for $\mathrm{PM}_{2.5}$ both at UB sites (267) and especially at RB sites (92). The EMEP network database includes fewer sites than AirBase, but it is the only European network providing $\mathrm{PM}_{10}$ speciation data, which are crucial to investigate the model performance deeper.

At EMEP stations, high-volume Whatman quartz filters or tapered element oscillating microbalance (TEOM) samplers are use to perform $\mathrm{PM}_{10}$ measurements. The measured quantities are analysed mainly with the gravimetric method; however, the micro balance technique is used in some countries. One should be aware that the reactivity of $\mathrm{NO}_{3}$ and the volatile character of $\mathrm{NH}_{4} \mathrm{NO}_{3}$ results in an underestimation of the measured concentrations, especially during the summer. Hence, according to Putaud et al. (2004), an uncertainty of $\pm 15 \%$ should be considered for major SIA species. Details about the station type classifications and the different measurement techniques are available through the AirBase and EMEP websites.

\subsection{Data analysis methodology}

In this paper, an "operational evaluation" is performed (Dennis et al., 2010). The evaluation techniques include statistical and graphical analyses applied in order to determine the degree of agreement between the model and the observations in an overall sense. We selected different statistical indicators for their ability to diagnose the model performance from different perspectives including temporal correlation, bias and the absolute error between observation and modelled values. Therefore, along with the observed $(\mathrm{OM})$ and modelled (MM) mean concentrations, the observed ( $\sigma \_$obs) and modelled ( $\sigma \_$mod) standard deviation, the correlation coefficient $(R)$, the root mean square error (RMSE), the fractional bias (FB) and the fractional error (FE) are calculated. Details about the calculation of the statistics performed using the Atmospheric Model Evaluation Tool software (AMET) can be found in Appel et al. (2011). The performance evaluation was based on yearly and seasonal statistics using the daily mean values of all stations available for the given typology (UB and RB).

\section{Model results}

\subsection{Spatio-temporal variability of the modelled concentrations}

In this section, the 2-D annual mean concentration maps of $\mathrm{NO}_{2}, \mathrm{O}_{3}, \mathrm{PM}_{10}$ and $\mathrm{PM}_{2.5}$ (Fig. 6) are analysed. On each map, the observed concentration values at each station are represented by a coloured dot for both RB and UB stations. The winter (December-January-February) and the summer (June-July-August) seasonal means are also drawn to analyse the inter-seasonal variability of the modelled concentrations of $\mathrm{NO}_{2}$ and $\mathrm{O}_{3}$ (Fig. 7), $\mathrm{PM}_{10}$ and $\mathrm{PM}_{2.5}$ (Fig. 8), SOA, dust and sea salt (Fig. 9), $\mathrm{SO}_{2}$ and sulfate (Fig. 10), and finally nitrate and ammonium species (Fig. 11).

$\mathrm{NO}_{2}$ concentrations are directly linked to emissions mainly coming from SNAP 2 (non-industrial combustion plants), 7 (road traffic) and 8 (other mobile source). Therefore, Fig. 6 shows that the highest annual mean concentrations are located over urban areas and along ship tracks (Atlantic Ocean, English Channel, and Mediterranean Sea). Specific areas with high concentrations are identified: the Po valley, Paris, the Benelux countries, London, southern Poland (e.g. Katowice), Athens, Madrid and Barcelona. For these specific areas, as well as over Europe, the concentrations are much higher during winter than during summer due to higher emissions and light vertical dispersion (e.g. shallow boundary layer height, stagnant conditions, thermal inversion) (Fig. 7). Ship tracks in the Mediterranean Sea, along the coast of Portugal and especially in the English Channel are characterized by rather high $\mathrm{NO}_{2}$ yearly mean modelled concentrations, ranging between 2 and $12 \mathrm{ppb}$. The observation values represented by the dots show a systematic underestimation of the $\mathrm{NO}_{2}$ concentrations over land, with a negative bias around $4 \mathrm{ppb}$. Moreover, two main areas located over the south of Poland (Katowice) and some parts of Romania (industrial hot spots) show an even larger underestimation (10-20 ppb). Conversely, some areas where the observations are overestimated are Paris, London, Madrid, Barcelona and Athens. For these areas, the methodology used to downscale the national annual emissions could be the reason for the overestimation. 

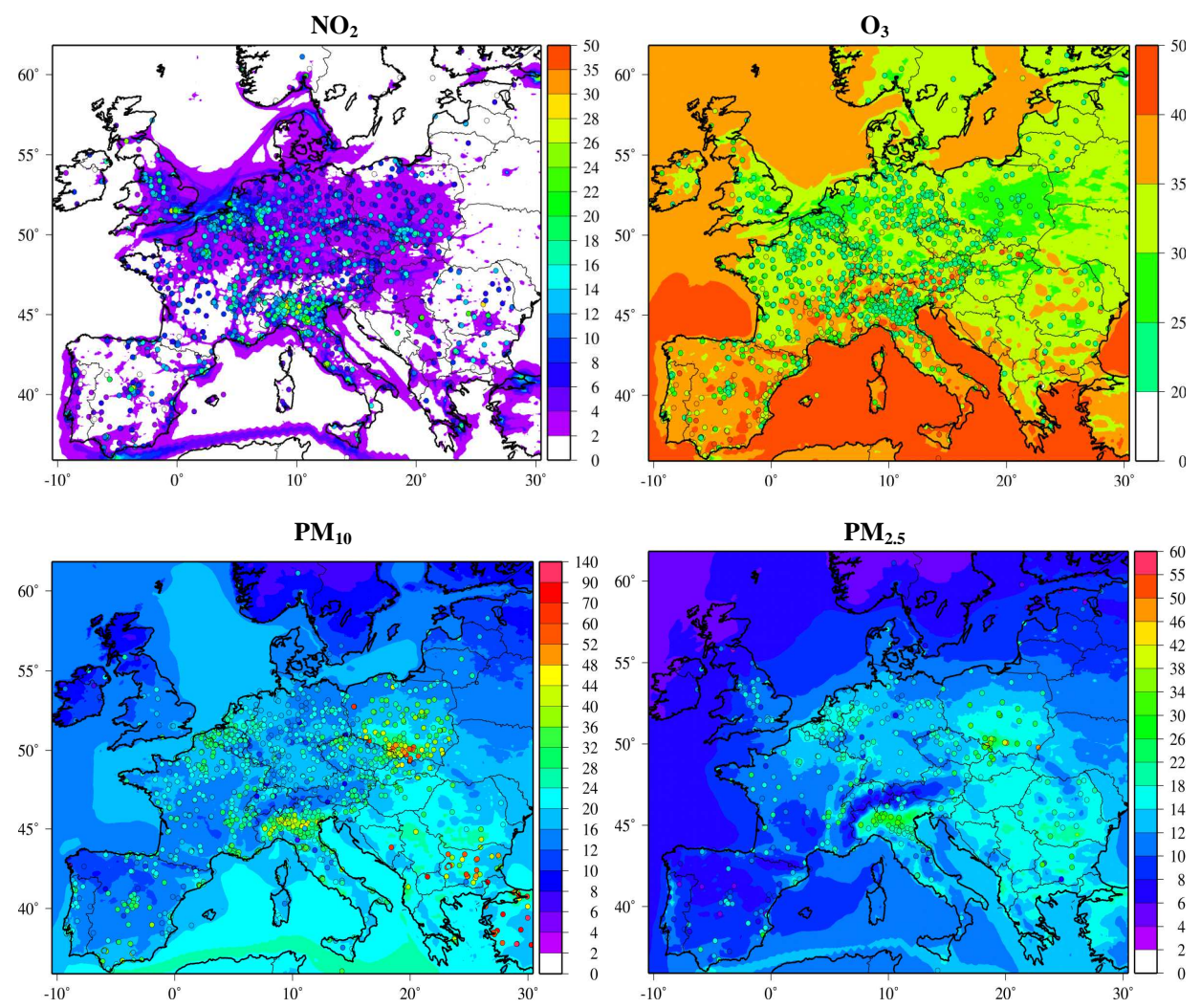

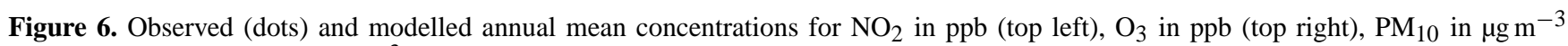
(bottom left) and $\mathrm{PM}_{2.5}$ in $\mu \mathrm{g} \mathrm{m}^{-3}$ (bottom right).

Overall, CHIMERE slightly overestimates $\mathrm{O}_{3}$ concentrations over Europe. Figure 6 shows that the highest annual mean concentrations are located below the $45^{\circ}$ latitude (from $30 \mathrm{ppb}$ over the coasts to $48 \mathrm{ppb}$ over the sea) where the strongest photolysis over Europe occurs. The $\mathrm{O}_{3}$ maximum concentrations are modelled during summer while the winter seasonal mean is below $30 \mathrm{ppb}$ over most of Europe, reaching values close to zero in the Benelux countries, the Po valley, Germany and Poland. The highest summer concentrations are calculated over and around the Mediterranean Sea, where lower boundary layer heights (as compared to continental planetary boundary layer heights), strong photolysis rates and low dry deposition constitute favourable conditions for the build-up of high $\mathrm{O}_{3}$ concentrations (up to $56 \mathrm{ppb}$ ). During the warm periods (spring and summer), most of the capital cities across Europe are characterized by ozone decrements due to the ozone titration by $\mathrm{NO}_{\mathrm{x}}$ as well as along shipping routes in northern Europe and the Strait of Gibral$\operatorname{tar}$ (Fig. 7).

For $\mathrm{PM}_{10}$, the highest modelled concentrations (20$30 \mu \mathrm{g} \mathrm{m}^{-3}$ ) are located south of a line that goes from the south of Portugal to the north of Poland (Fig. 6). The annual mean concentrations show a slight underestimation over the continent. However, over cities such as Milan, Paris and Krakow, CHIMERE overestimates the observations, likely due to the methodology used to downscale the SNAP2 emissions from biomass burning, which are still too concentrated over the centre of the urban areas instead of being more distributed over the surrounding areas (Timmermans et al., 2014). In winter, the modelled concentrations are highest over the continent $\left(10-30 \mu \mathrm{g} \mathrm{m}^{-3}\right)$, with lower concentrations over central Spain $\left(10 \mu \mathrm{g} \mathrm{m}^{-3}\right)$. Hot spots are located over the large European urban areas and over industrial primary emissions areas (e.g. Romania and Bulgaria). In summer, the concentrations are strongly influenced by the amount of dust and boundary conditions in the south part of the domain (up to $36 \mu \mathrm{g} \mathrm{m}^{-3}$ ) and the urban $\mathrm{PM}_{10}$ pattern is weak except for Katowice, Milan and Paris (28-50 $\mu \mathrm{g} \mathrm{m}^{-3}$ ) (Fig. 8). The concentrations over the continent are a factor of 2 lower than the hot spot areas. In winter, much lower concentrations are modelled over the Mediterranean Sea (16$18 \mu \mathrm{g} \mathrm{m}^{-3}$ ) due to the lower influence of Saharan dust with respect to the summer season. Primary emissions from the large cities and industrial areas have their strongest intensity during winter. Three hot spots can be identified: the Po valley, the south of Poland (Katowice region) and the south of Romania (area of Bucharest). Indeed, very high $\mathrm{PM}_{10}$ concentrations are modelled throughout the year over these areas. The complex topography and the large primary emissions (SNAP 1, 2 and 7) are the main reasons for the high concen- 

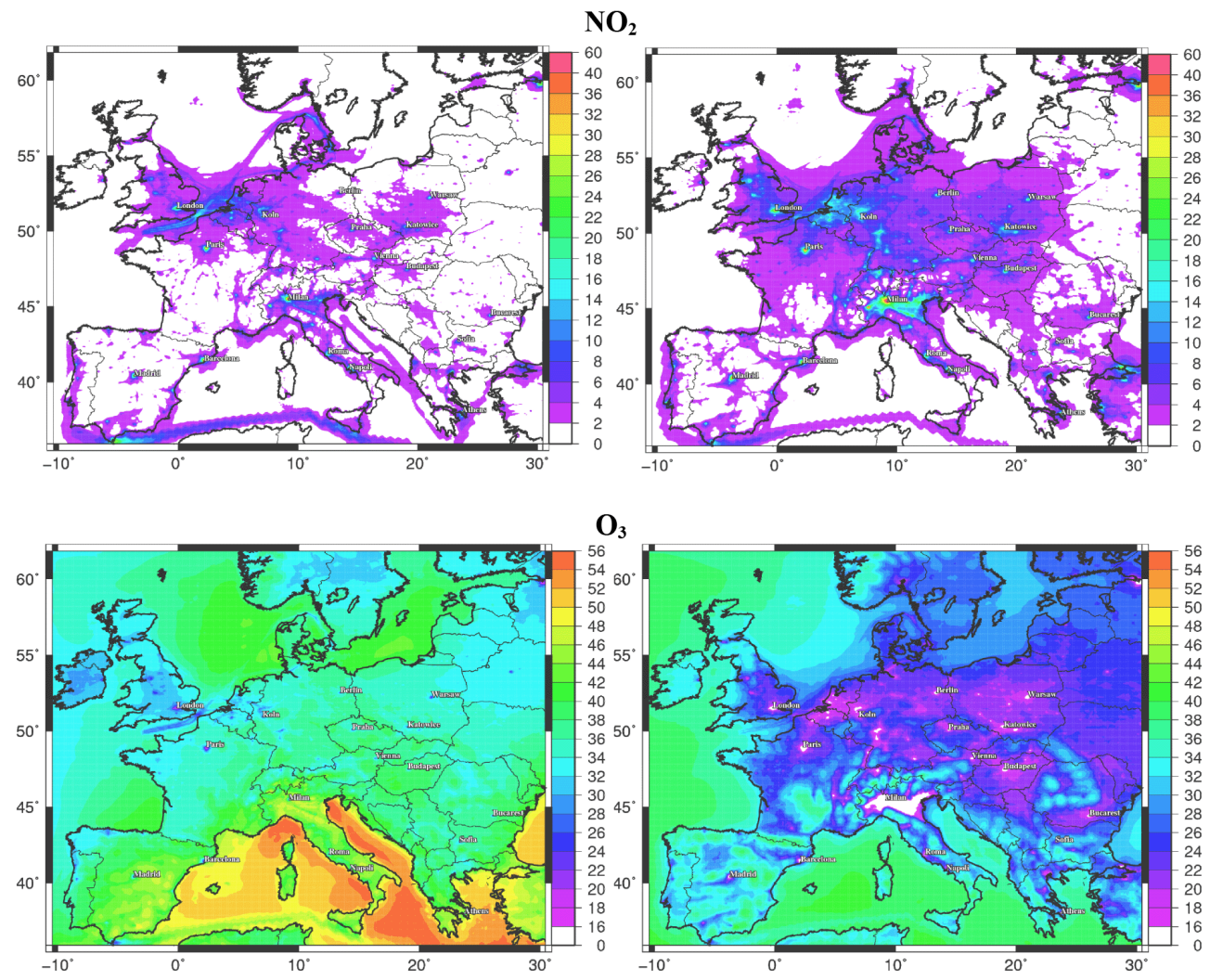

Figure 7. Modelled $\mathrm{NO}_{2}$ and $\mathrm{O}_{3}(\mathrm{ppb})$ concentrations fields calculated for the summer (left) and the winter (right) season.

trations, as well as favourable meteorological conditions for SIA formation (low vertical and horizontal dispersion, high level of humidity during the cold seasons) that also play a major role in the build-up of high $\mathrm{PM}_{10}$ concentrations, especially in the Po valley.

For $\mathrm{PM}_{2.5}$ (Figs. 6 and 8), the pattern is similar to $\mathrm{PM}_{10}$. The highest concentrations are calculated over the Po valley during winter $\left(30-60 \mu \mathrm{g} \mathrm{m}^{-3}\right)$, while for the summer the highest concentrations are related to dust and are located over the south of Spain and northern Africa $\left(16-20 \mu \mathrm{g} \mathrm{m}^{-3}\right)$. In spring, high concentrations are calculated over the east of the Mediterranean Sea and are partially linked to the production of fine mode aerosol sulfate. The observations show a good agreement with the modelled concentrations fields, but a general underestimation is clearly evident over some Eastern Europe countries such as Poland and Bulgaria, as well as over the Po valley.

In order to have a better insight into modelled PM composition over Europe, the modelled concentrations for dust, sea salt, SOA (Fig. 9) and SIA (Figs. 10 and 11) are examined. The highest dust concentrations occur in the summer over north Africa (up to $30 \mu \mathrm{g} \mathrm{m}^{-3}$ ) and southern Spain (up to $25 \mu \mathrm{g} \mathrm{m}^{-3}$ ). In these regions, dust is by far $(90 \%)$ the largest $\mathrm{PM}_{10}$ component in the summer with a large contribution of the boundary conditions (largest of all seasons). The accuracy of the boundary conditions in this area is therefore of great importance in order to correctly model the $\mathrm{PM}_{10}$ concentrations. For sea salt, the highest values occur during the winter and are located over the North Sea (up to $13 \mu \mathrm{g} \mathrm{m}^{-3}$ ), where it represents the major part of the $\mathrm{PM}_{10}$ mass. Over land, a zonal gradient is observed, with a maximum concentration modelled over western Europe $\left(5 \mu \mathrm{g} \mathrm{m} \mathrm{m}^{-3}\right.$ over Ireland) and the minima over eastern Europe $\left(<1 \mu \mathrm{g} \mathrm{m}^{-3}\right)$, where the influence of oceanic winds carrying sea salt particles is lower than over the west of Europe. For SOA, the contrast between summer and winter is striking. In winter, the concentrations are low $\left(<1 \mu \mathrm{g} \mathrm{m}^{-3}\right)$, with a maximum in the Po valley $\left(4 \mu \mathrm{g} \mathrm{m}^{-3}\right)$, while during summer the concentrations over land range between $0.5 \mu \mathrm{g} \mathrm{m}^{-3}$ in the western part of Europe and $8 \mu \mathrm{g} \mathrm{m}^{-3}$ over the Balkans.

For sulfate (Fig. 10), during winter a sharp zonal gradient is observed, with modelled minima in western Europe $\left(2 \mu \mathrm{g} \mathrm{m}^{-3}\right.$ on average) and maxima in eastern Europe (up to $\left.8 \mu \mathrm{g} \mathrm{m}^{-3}\right)$. The highest concentrations are located near the main $\mathrm{SO}_{2}$ industrial and urban emission areas in Romania, Bulgaria, Bosnia, Serbia, Hungary and south Poland that use sulfur-rich coal for energy production and domestic heating (e.g. in the Katowice region). During the summer, sulfate resulting from the gas oxidation of $\mathrm{SO}_{2}$ occurs mainly over the Mediterranean Sea, where emissions from ships are high and intense photolysis allows for the production of oxidant radicals (e.g. OH radical). The stagnant meteorological con- 

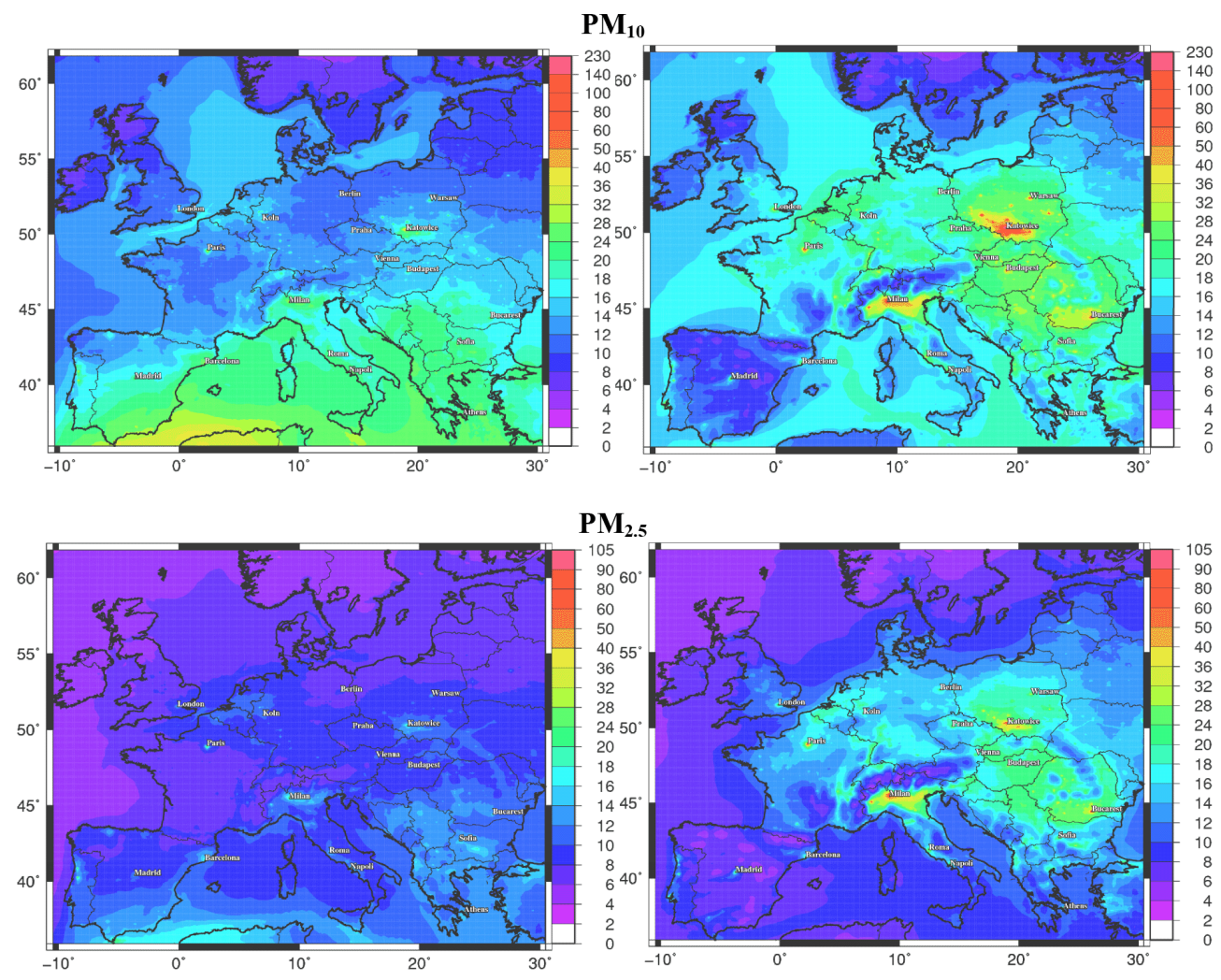

Figure 8. Modelled $\mathrm{PM}_{10}$ and $\mathrm{PM}_{2.5}\left(\mu \mathrm{g} \mathrm{m}^{-3}\right)$ concentrations fields calculated for the summer (left) and the winter (right) seasons.

ditions in summer also favour accumulation and recirculation of pollutants in the Mediterranean basin.

For ammonium and nitrate (Fig. 11) a strong seasonal variability is modelled, with lower concentrations in summer than in winter. Nitrate concentrations correspond less to precursor emission pattern than sulfate, due to the influence of a more complex chemical transformation pathway (e.g. the thermodynamical equilibrium with ammonium). The highest modelled concentrations are seen during winter over the Po valley (up to $15 \mu \mathrm{g} \mathrm{m}^{-3}$ ), over the Benelux countries $\left(6 \mu \mathrm{g} \mathrm{m}^{-3}\right)$ and in southern Germany $\left(8 \mu \mathrm{g} \mathrm{m}^{-3}\right)$. Ammonium wintertime concentrations show a wide and rather homogeneous pattern, covering both western and eastern Europe, together with a hot spot covering the entire Po valley (up to $5.2 \mu \mathrm{g} \mathrm{m}^{-3}$ ), due to abundant emissions and frequent weak circulation conditions. Ammonium concentrations in western Europe are mainly driven by nitrate availability, whereas in Eastern Europe the ammonium spatial pattern is closely related to the sulfate pattern.

\subsection{Model evaluation}

Tables 4 and 5 display the different yearly and seasonal statistics for $\mathrm{SO}_{2}, \mathrm{NO}_{2}, \mathrm{O}_{3}, \mathrm{PM}_{10}$, and $\mathrm{PM}_{2.5}$ at RB and UB AirBase stations respectively. Table 6 displays the same metrics computed at EMEP monitoring network sites and also in-
Table 3. Number of stations available per species and network over the domain of simulation ( $\mathrm{x}=$ no stations available).

\begin{tabular}{lcrr}
\hline & \multicolumn{2}{c}{ Number of stations } & \multirow{2}{*}{ Unit } \\
\cline { 2 - 3 } & UB & RB & \\
\hline AirBase & & & \\
\hline $\mathrm{SO}_{2}$ & 524 & 183 & $\mathrm{ppb}$ \\
$\mathrm{NO}_{2}$ & 770 & 300 & $\mathrm{ppb}$ \\
$\mathrm{O}_{3}$ & 586 & 361 & $\mathrm{ppb}$ \\
$\mathrm{PM}_{10}$ & 677 & 238 & $\mu \mathrm{g} \mathrm{m}^{-3}$ \\
$\mathrm{PM}_{2.5}$ & 267 & 92 & $\mu \mathrm{g} \mathrm{m}^{-3}$ \\
\hline EMEP & & & \\
\hline $\mathrm{PM}_{10}$ & $\mathrm{x}$ & 21 & $\mu \mathrm{g} \mathrm{m}^{-3}$ \\
$\mathrm{PM}_{2.5}$ & $\mathrm{x}$ & 17 & $\mu \mathrm{g} \mathrm{m}^{-3}$ \\
Sulfate & $\mathrm{x}$ & 37 & $\mu \mathrm{gS} \mathrm{m}^{-3}$ \\
Nitrate & $\mathrm{x}$ & 17 & $\mu \mathrm{gN} \mathrm{m}^{-3}$ \\
Total nitrate & $\mathrm{x}$ & 26 & $\mu \mathrm{gN} \mathrm{m}^{-3}$ \\
Ammonium & $\mathrm{x}$ & 17 & $\mu \mathrm{gN} \mathrm{m}^{-3}$ \\
Total ammonia & $\mathrm{x}$ & 14 & $\mu \mathrm{gN} \mathrm{m}^{-3}$ \\
\hline
\end{tabular}

cludes sulfate, nitrate, total nitrate, ammonium and total ammonia. The daily box-whisker plots time series of $\mathrm{SO}_{2}, \mathrm{NO}_{2}$, $\mathrm{O}_{3}, \mathrm{PM}_{10}$ and $\mathrm{PM}_{2.5}$ species computed at RB (Fig. 5s) and 

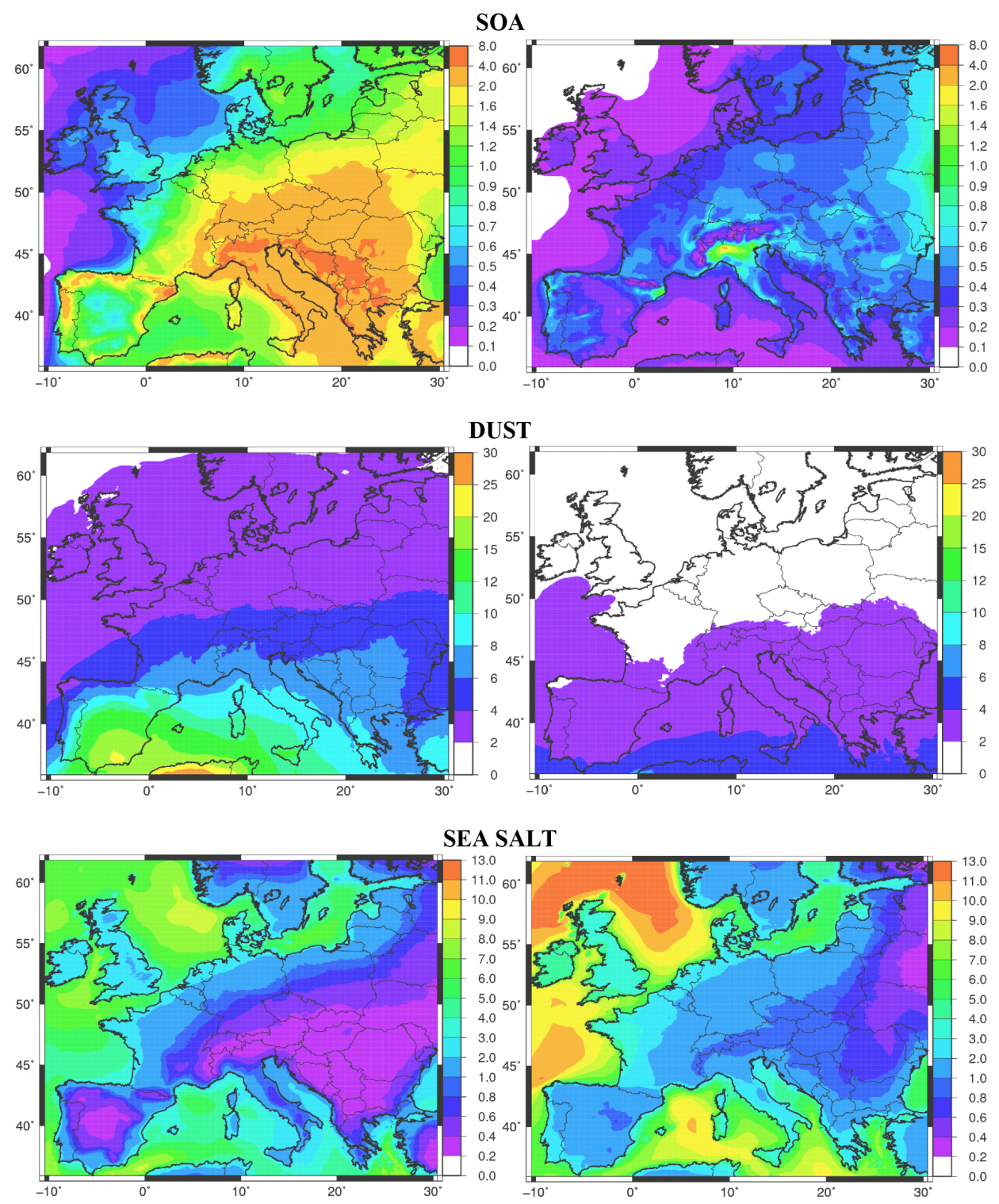

Figure 9. Modelled SOA, dust and sea salt $\left(\mu \mathrm{g} \mathrm{m}^{-3}\right)$ concentrations fields calculated for the summer (left) and the winter (right) seasons.

UB (Fig. 6s) stations respectively, as well as sulfate, total nitrate and total ammonia calculated using the EMEP stations data (Fig. 7s), are available in the supplement.

\subsubsection{Sulfur dioxide}

The model underestimates the $\mathrm{SO}_{2}$ concentrations (factor of 2 for the median values) over the year at $\mathrm{RB}$ sites $(\mathrm{FB}=$ $-46.0 \%)$. This behaviour contradicts the results of Pay et al. (2010), showing that the CMAQ model tends to overestimate the $\mathrm{SO}_{2}$ concentrations at $\mathrm{RB}$ sites over Europe. The temporal correlation is relatively high over the year $(R=0.57)$ and especially in winter $(R=0.67)$, where some maxima are correctly represented by the model. The FB is relatively low in the winter $(-30.0 \%)$ compared to the rest of the year.

At UB stations, the bias between model and observed values is low $(\mathrm{OM}=2.16 \mathrm{ppb} ; \mathrm{MM}=2.25 \mathrm{ppb})$. However, the temporal correlation is relatively constant throughout the year and rather low $(\mathrm{R}=0.30$ over the year). The model overestimates the $\mathrm{SO}_{2}$ observed peaks in January, February and December. Over the year, the 95th observed quantile $(7.1 \mathrm{ppb})$ is slightly overestimated by the model $(8.5 \mathrm{ppb})$. Hence, the FB is positive but significantly lower $(2.35 \%)$ than at RB stations. 

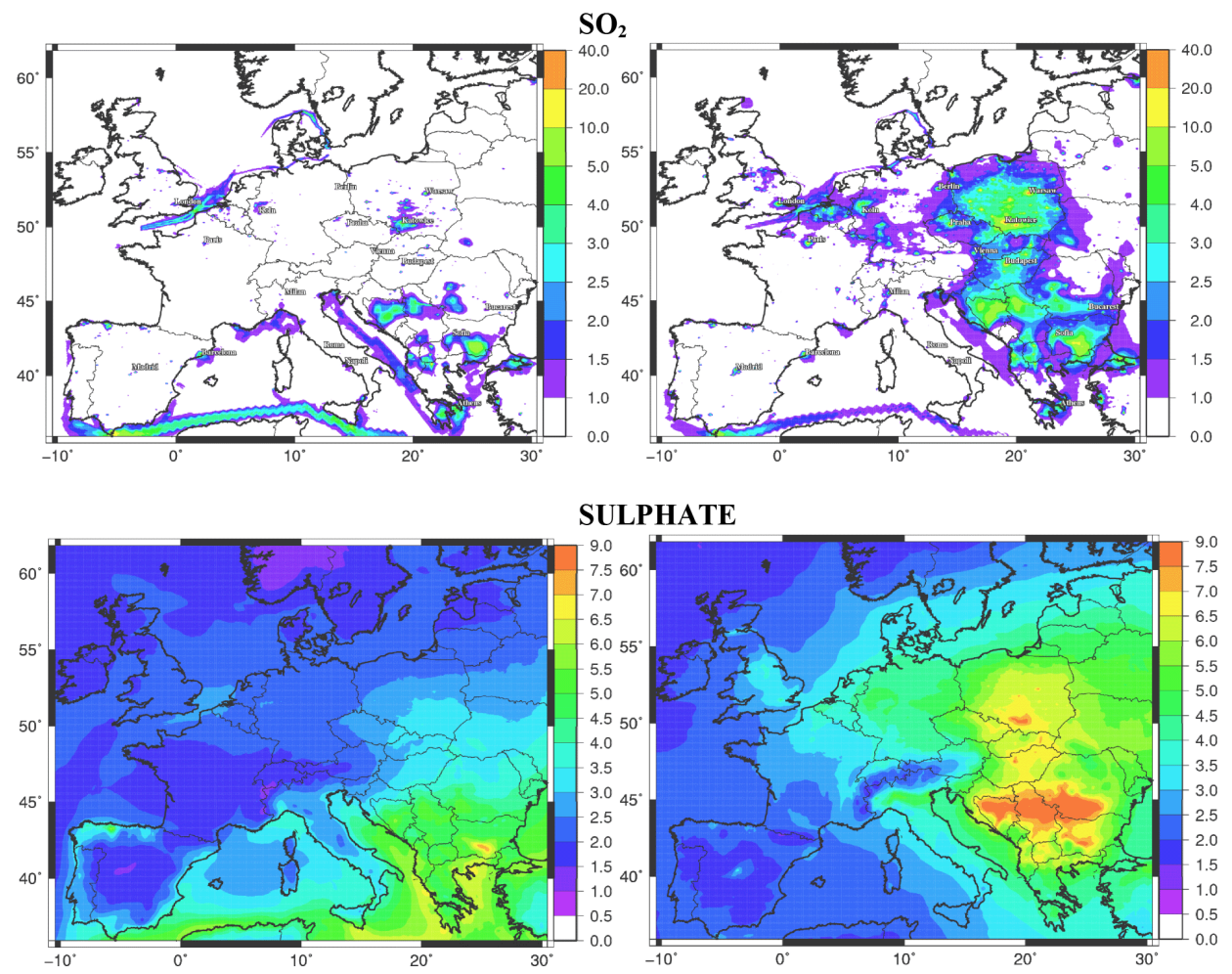

Figure 10. Modelled $\mathrm{SO}_{2}(\mathrm{ppb})$ and sulfate $\left(\mu \mathrm{g} \mathrm{m}^{-3}\right)$ concentrations fields calculated for the summer (left) and the winter (right) seasons.
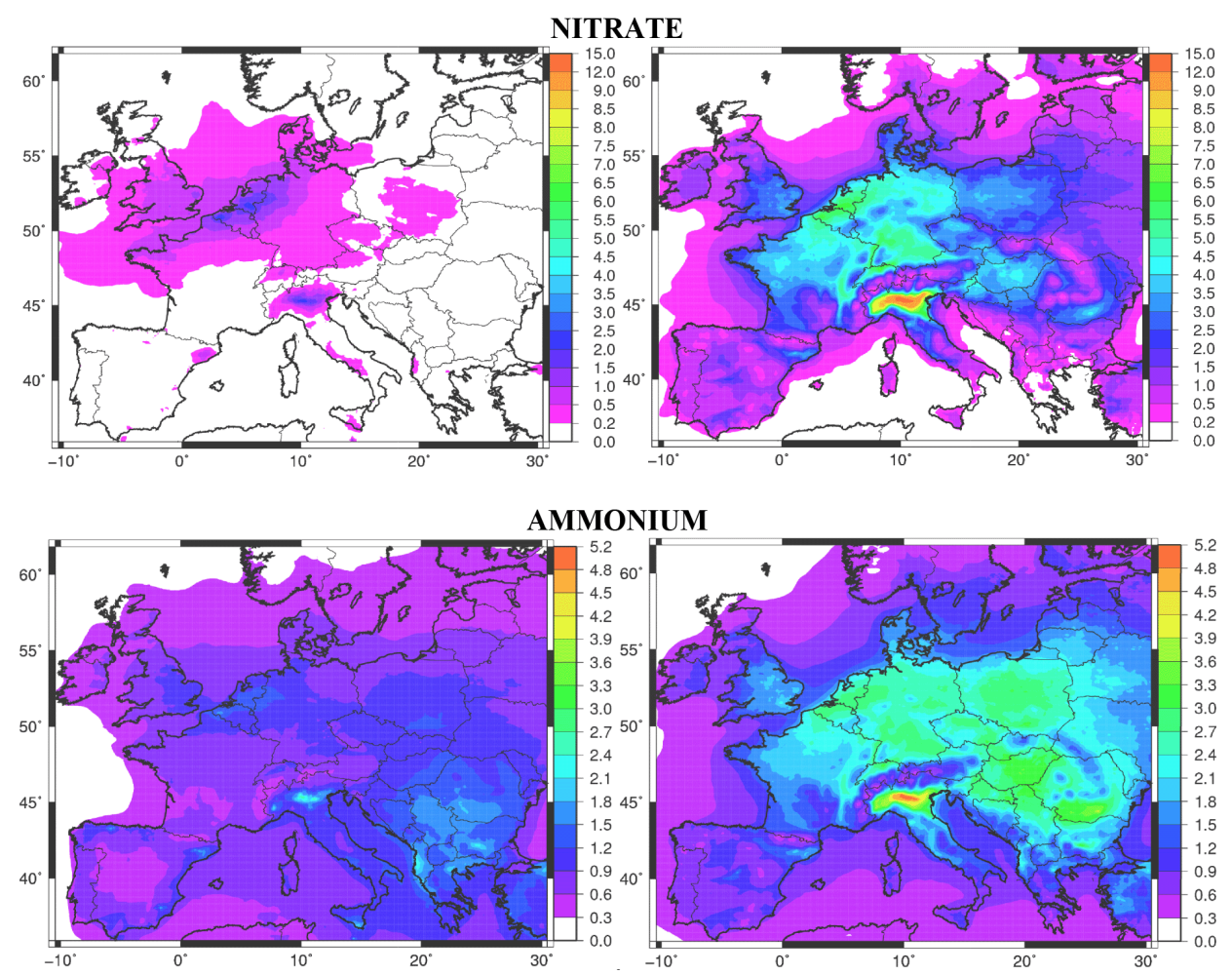

Figure 11. Modelled nitrate and ammonium $\left(\mu \mathrm{g} \mathrm{m}^{-3}\right)$ concentrations fields calculated for the summer (left) and the winter (right) season. 
Table 4. Annual and seasonal scores calculated using the whole RB AirBase set of stations. The statistics are: the OM, the MM, the standard deviation of the observations ( $\sigma \_$obs) and modelled values ( $\sigma \_$mod), the correlation coefficient $(R)$, the RMSE, the FB $(\%)$ and FE $(\%)$. $N_{\text {OBS }}$ is the number of observations. The units of the statistical indexes for each pollutant are reported in Table 3 . $R$ is unitless.

\begin{tabular}{|c|c|c|c|c|c|c|c|c|c|}
\hline & $N_{\mathrm{OBS}}$ & $\mathrm{OM}$ & MM & $\sigma \_$obs & $\sigma \_\bmod$ & $R$ & RMSE & FB & $\mathrm{FE}$ \\
\hline \multicolumn{10}{|l|}{$\mathrm{SO}_{2}$} \\
\hline Annual & 60740 & 1.08 & 0.69 & 0.80 & 0.65 & 0.57 & 1.27 & -46.0 & 88.0 \\
\hline Spring & 15373 & 1.43 & 0.57 & 1.07 & 0.47 & 0.33 & 2.02 & -68.0 & 103.0 \\
\hline Summer & 15543 & 1.43 & 0.43 & 1.07 & 0.35 & 0.25 & 2.12 & -84.0 & 112.0 \\
\hline Autumn & 15373 & 1.43 & 0.58 & 1.07 & 0.49 & 0.25 & 2.10 & -70.0 & 104.0 \\
\hline Winter & 9978 & 1.63 & 1.30 & 1.22 & 1.18 & 0.67 & 1.71 & -30.0 & 80.0 \\
\hline \multicolumn{10}{|l|}{$\mathrm{NO}_{2}$} \\
\hline Annual & 98833 & 6.55 & 4.63 & 5.75 & 4.37 & 0.68 & 4.67 & -33.9 & 53.4 \\
\hline Spring & 25173 & 5.66 & 3.94 & 4.41 & 3.50 & 0.63 & 3.90 & -37.9 & 56.1 \\
\hline Summer & 24168 & 4.22 & 3.27 & 3.15 & 2.60 & 0.53 & 2.97 & -26.0 & 50.4 \\
\hline Autumn & 24929 & 6.58 & 5.04 & 4.97 & 4.56 & 0.67 & 4.20 & -29.5 & 50.4 \\
\hline Winter & 16105 & 10.23 & 6.22 & 8.36 & 5.59 & 0.69 & 7.26 & -46.5 & 59.3 \\
\hline \multicolumn{10}{|l|}{$\mathrm{O}_{3}$} \\
\hline Annual & 122518 & 28.60 & 33.45 & 11.13 & 8.65 & 0.77 & 8.59 & 20.1 & 26.3 \\
\hline Spring & 31787 & 35.12 & 38.71 & 9.19 & 6.35 & 0.59 & 8.29 & 11.9 & 19.4 \\
\hline Summer & 31865 & 33.91 & 37.77 & 9.30 & 6.28 & 0.65 & 8.05 & 13.1 & 19.5 \\
\hline Autumn & 30074 & 23.50 & 30.26 & 9.74 & 7.12 & 0.71 & 9.64 & 30.6 & 34.9 \\
\hline Winter & 18941 & 21.65 & 27.56 & 8.68 & 8.08 & 0.70 & 8.82 & 27.4 & 33.1 \\
\hline \multicolumn{10}{|l|}{$\mathrm{PM}_{10}$} \\
\hline Annual & 77828 & 20.67 & 17.90 & 14.93 & 9.65 & 0.62 & 12.02 & -5.50 & 37.7 \\
\hline Spring & 19656 & 21.41 & 20.01 & 14.25 & 9.54 & 0.60 & 11.49 & 2.10 & 36.0 \\
\hline Summer & 19639 & 17.17 & 14.41 & 8.63 & 6.54 & 0.50 & 8.26 & -13.3 & 35.7 \\
\hline Autumn & 19459 & 19.28 & 18.19 & 12.36 & 10.16 & 0.64 & 9.77 & 0.30 & 37.3 \\
\hline Winter & 12374 & 27.20 & 18.94 & 22.45 & 11.11 & 0.67 & 18.95 & -20.3 & 43.6 \\
\hline \multicolumn{10}{|l|}{$\mathrm{PM}_{2.5}$} \\
\hline Annual & 27574 & 13.69 & 12.78 & 12.59 & 7.96 & 0.71 & 8.99 & 7.50 & 40.4 \\
\hline Spring & 6737 & 14.80 & 14.71 & 12.05 & 7.44 & 0.67 & 8.95 & 13.2 & 39.1 \\
\hline Summer & 7043 & 9.87 & 9.11 & 5.50 & 3.74 & 0.53 & 4.80 & 0.40 & 36.9 \\
\hline Autumn & 7151 & 12.29 & 12.44 & 10.29 & 7.68 & 0.71 & 7.31 & 14.2 & 42.1 \\
\hline Winter & 4186 & 20.05 & 15.16 & 19.78 & 10.70 & 0.74 & 14.73 & -8.70 & 43.5 \\
\hline
\end{tabular}

\subsubsection{Nitrogen dioxide}

Throughout the year, CHIMERE accurately reproduces the temporal variability of $\mathrm{NO}_{2}$ at the $\mathrm{RB}$ sites $(R=0.68)$, but with a large negative bias $(\mathrm{FB}=-33.9 \%)$, particularly during winter $(\mathrm{FB}=-44.5 \%)$.

At UB stations, although the temporal variability is rather well reproduced $(R=0.61)$, the model underestimation is even larger than at RB sites, both over the entire year $(\mathrm{FB}=$ $-53.6 \%)$ and especially during the winter season $(\mathrm{FB}=$ $-63.9 \%)$. This poor performance could be explained by the general underestimation of urban $\mathrm{NO}_{\mathrm{x}}$ emissions, especially in the Eastern European cities. Moreover, the yearly mean UB diurnal cycle (Fig. 8s) shows a rather persistent negative bias throughout the day ( $4 \mathrm{ppb}$ in mean). Nevertheless, the bias is largest during the morning ( 8 a.m.) and evening traffic ( 8 p.m.) peaks, indicating a very likely underestimation of the $\mathrm{NO}_{\mathrm{x}}$ traffic emissions over urban areas.

At both RB and UB stations, CHIMERE usually performs better in reproducing the temporal variability of the observed concentrations (e.g. standard deviation and correlation coefficient) than the mean values. Further investigation of the model behaviour over urban areas performed using the DELTA tool (Thunis et al., 2012) indicates that the performance of CHIMERE is significantly better over large European cities' (e.g. capitals') UB stations than over the UB stations of medium-size and small cities. The bias between observed and modelled concentrations is reduced from $4.58 \mathrm{ppb}$ when using all UB available stations to $1.31 \mathrm{ppb}$ when focusing on the largest 30 cities of Europe. Conversely, the 
Table 5. Annual and seasonal scores calculated using the whole UB AirBase set of stations. The indicators and the associated units are identical to those in Table 4.

\begin{tabular}{|c|c|c|c|c|c|c|c|c|c|}
\hline & $N_{\mathrm{OBS}}$ & $\mathrm{OM}$ & MM & $\sigma \_$obs & $\sigma \_\bmod$ & $R$ & RMSE & FB & FE \\
\hline \multicolumn{10}{|l|}{$\mathrm{SO}_{2}$} \\
\hline Annual & 165710 & 2.16 & 2.25 & 1.88 & 2.12 & 0.30 & 4.64 & 2.35 & 91.0 \\
\hline Spring & 44543 & 3.19 & 2.06 & 2.88 & 1.86 & 0.23 & 6.26 & -27.0 & 96.0 \\
\hline Summer & 45044 & 3.19 & 1.16 & 2.87 & 0.99 & 0.23 & 6.23 & -59.0 & 105.0 \\
\hline Autumn & 44543 & 3.19 & 2.01 & 2.88 & 1.86 & 0.18 & 6.47 & -29.0 & 99.0 \\
\hline Winter & 14403 & 3.65 & 3.87 & 3.29 & 3.38 & 0.30 & 7.33 & 8.00 & 86.0 \\
\hline \multicolumn{10}{|l|}{$\mathrm{NO}_{2}$} \\
\hline Annual & 264005 & 13.15 & 8.57 & 8.14 & 8.09 & 0.61 & 8.48 & -53.6 & 66.6 \\
\hline Spring & 67205 & 12.34 & 7.91 & 6.93 & 7.71 & 0.59 & 8.02 & -57.8 & 70.4 \\
\hline Summer & 65960 & 8.97 & 6.64 & 5.14 & 6.53 & 0.51 & 6.34 & -44.0 & 63.7 \\
\hline Autumn & 65665 & 13.39 & 9.13 & 7.52 & 8.40 & 0.64 & 8.05 & -51.7 & 64.0 \\
\hline Winter & 42984 & 18.65 & 10.77 & 9.98 & 9.15 & 0.64 & 11.37 & -63.9 & 70.5 \\
\hline \multicolumn{10}{|l|}{$\mathrm{O}_{3}$} \\
\hline Annual & 190716 & 24.90 & 30.71 & 10.95 & 9.43 & 0.73 & 9.62 & 25.2 & 33.4 \\
\hline Spring & 51219 & 30.31 & 35.30 & 9.21 & 7.91 & 0.56 & 9.54 & 16.9 & 25.9 \\
\hline Summer & 51195 & 31.08 & 35.29 & 9.36 & 7.28 & 0.62 & 8.60 & 14.9 & 22.7 \\
\hline Autumn & 46215 & 19.80 & 27.46 & 9.07 & 7.90 & 0.64 & 10.60 & 36.9 & 43.0 \\
\hline Winter & 28040 & 17.02 & 24.18 & 7.91 & 8.83 & 0.62 & 10.28 & 35.6 & 45.5 \\
\hline \multicolumn{10}{|l|}{$\mathrm{PM}_{10}$} \\
\hline Annual & 226954 & 29.27 & 22.56 & 22.98 & 16.61 & 0.52 & 21.29 & -20.1 & 40.8 \\
\hline Spring & 57618 & 28.65 & 24.03 & 18.59 & 13.89 & 0.50 & 17.33 & -12.2 & 37.5 \\
\hline Summer & 56778 & 21.50 & 16.62 & 11.05 & 7.81 & 0.47 & 11.18 & -22.4 & 38.6 \\
\hline Autumn & 57100 & 28.47 & 23.09 & 21.05 & 16.34 & 0.56 & 18.78 & -16.8 & 39.8 \\
\hline Winter & 36494 & 41.45 & 26.59 & 34.55 & 23.83 & 0.47 & 34.88 & -36.6 & 50.8 \\
\hline \multicolumn{10}{|l|}{$\mathrm{PM}_{2.5}$} \\
\hline Annual & 79664 & 17.52 & 15.07 & 14.65 & 10.29 & 0.65 & 11.39 & -6.40 & 37.8 \\
\hline Spring & 20200 & 17.28 & 16.59 & 12.53 & 8.36 & 0.59 & 10.16 & 5.20 & 36.1 \\
\hline Summer & 20093 & 11.91 & 10.05 & 6.13 & 4.28 & 0.46 & 5.94 & -11.5 & 36.8 \\
\hline Autumn & 20932 & 16.46 & 14.65 & 12.43 & 9.74 & 0.69 & 9.26 & -4.00 & 37.5 \\
\hline Winter & 11344 & 27.53 & 19.67 & 23.01 & 14.97 & 0.61 & 19.87 & -24.6 & 43.3 \\
\hline
\end{tabular}

adopted horizontal resolution which increases the dilution of the emitted pollutants is not able to accurately simulate the spatial gradient of the emissions over medium-size and small cities, giving rise to the underestimation of the observed concentrations.

\subsubsection{Ozone}

Similarly to $\mathrm{NO}_{2}$, the daily temporal variability of $\mathrm{O}_{3}$ concentrations is well reproduced at both $\mathrm{RB}(R=0.77)$ and UB sites $(R=0.73)$. The comparison of modelled and observed concentrations quantiles shows that the highest values are well reproduced while lower quantiles are overestimated (Figs. 5s and 6s). Throughout the year, the modelled values show a rather homogeneous bias which is higher at UB $(\mathrm{FB}=25.2 \%)$ than at $\mathrm{RB}$ sites $(20.1 \%)$ and is likely linked to the $\mathrm{NO}_{\mathrm{x}}$ underestimation that is larger at $\mathrm{UB}$ than at $\mathrm{RB}$, thus limiting the $\mathrm{O}_{3}$ titration by $\mathrm{NO}_{2}$. The yearly mean diurnal cycle (Fig. 9s) shows a larger positive bias ( $9 \mathrm{ppb}$ ) during the morning $(7 \mathrm{a} . \mathrm{m}$.) than during the afternoon ozone peak ( $5 \mathrm{ppb}$ in mean). This tendency is likely also related to the lack of $\mathrm{O}_{3}$ titration by $\mathrm{NO}_{2}$ due to the previously described larger underestimation of $\mathrm{NO}_{2}$ in the morning (e.g. 8 a.m.).

The $\mathrm{FB}$ of $\mathrm{O}_{3}$ has a seasonal variation, with a low positive FB in the summer $(14.9 \%)$ and the highest overestimations during the autumn at $\mathrm{RB}(\mathrm{FB}=30.6 \%)$ and $\mathrm{UB}$ sites $(\mathrm{FB}=36.9 \%)$.Data from the remote Valentia observatory station $\left(51.94^{\circ} \mathrm{N} ; 10.24^{\circ} \mathrm{W}\right)$, located in Ireland at the western lateral boundary of the domain, show that the background concentrations are slightly overestimated throughout the year (2.4 ppb for the median), with a maximum during the autumn (12 ppb for the median). The lateral boundary condi- 
Table 6. Annual and seasonal scores calculated using the RB EMEP stations. The indicators and the associated units are identical to those in Table 4.

\begin{tabular}{|c|c|c|c|c|c|c|c|c|c|}
\hline & $N_{\text {OBS }}$ & $\mathrm{OM}$ & MM & $\sigma \_$obs & $\sigma \_\bmod$ & $R$ & RMSE & FB & FE \\
\hline \multicolumn{10}{|l|}{$\mathrm{PM}_{10}$} \\
\hline Annual & 6579 & 16.72 & 15.91 & 11.03 & 7.56 & 0.56 & 9.29 & 2.90 & 35.4 \\
\hline Spring & 1697 & 18.26 & 18.11 & 12.08 & 8.47 & 0.49 & 10.83 & 7.20 & 35.2 \\
\hline Summer & 1648 & 14.66 & 13.86 & 7.46 & 6.42 & 0.46 & 7.31 & -2.30 & 32.1 \\
\hline Autumn & 1620 & 15.25 & 15.93 & 8.80 & 7.75 & 0.65 & 6.98 & 9.80 & 35.3 \\
\hline Winter & 1056 & 20.48 & 15.47 & 14.88 & 7.12 & 0.68 & 12.33 & -14.4 & 39.4 \\
\hline \multicolumn{10}{|l|}{$\mathrm{PM}_{2.5}$} \\
\hline Annual & 4858 & 11.69 & 10.90 & 9.62 & 5.35 & 0.68 & 7.22 & 8.60 & 42.0 \\
\hline Spring & 1242 & 13.27 & 12.71 & 10.48 & 5.74 & 0.62 & 8.28 & 12.3 & 41.6 \\
\hline Summer & 1202 & 8.69 & 8.60 & 4.55 & 3.39 & 0.36 & 4.58 & 5.80 & 39.1 \\
\hline Autumn & 1217 & 10.00 & 10.32 & 7.12 & 4.78 & 0.67 & 5.30 & 15.7 & 42.7 \\
\hline Winter & 767 & 16.32 & 11.78 & 13.76 & 6.43 & 0.77 & 10.72 & -11.6 & 45.7 \\
\hline \multicolumn{10}{|l|}{ Sulfate } \\
\hline Annual & 10596 & 0.73 & 1.07 & 0.62 & 0.67 & 0.50 & 0.72 & 42.4 & 55.3 \\
\hline Spring & 2830 & 0.75 & 1.19 & 0.54 & 0.56 & 0.57 & 0.67 & 53.7 & 60.8 \\
\hline Summer & 2576 & 0.69 & 0.79 & 0.42 & 0.39 & 0.46 & 0.44 & 20.1 & 42.5 \\
\hline Autumn & 2461 & 0.67 & 1.02 & 0.50 & 0.69 & 0.51 & 0.71 & 45.2 & 56.6 \\
\hline Winter & 1872 & 0.88 & 1.22 & 0.96 & 0.84 & 0.52 & 0.95 & 43.4 & 57.6 \\
\hline \multicolumn{10}{|l|}{ Nitrate } \\
\hline Annual & 4647 & 0.64 & 0.32 & 1.49 & 0.53 & 0.28 & 1.47 & -103.5 & 116.2 \\
\hline Spring & 1201 & 0.88 & 0.38 & 2.38 & 0.62 & 0.24 & 2.36 & -95.0 & 107.8 \\
\hline Summer & 1148 & 0.46 & 0.08 & 1.47 & 0.19 & 0.13 & 1.50 & -156.1 & 157.1 \\
\hline Autumn & 1141 & 0.49 & 0.28 & 0.59 & 0.44 & 0.48 & 0.58 & -99.4 & 113.3 \\
\hline Winter & 763 & 0.76 & 0.54 & 0.72 & 0.68 & 0.67 & 0.61 & -68.4 & 90.2 \\
\hline \multicolumn{10}{|c|}{ Total nitrate } \\
\hline Annual & 7327 & 0.60 & 0.37 & 0.62 & 0.40 & 0.56 & 0.56 & -55.1 & 71.6 \\
\hline Spring & 1907 & 0.68 & 0.43 & 0.65 & 0.42 & 0.67 & 0.54 & -50.7 & 66.8 \\
\hline Summer & 1844 & 0.46 & 0.23 & 0.62 & 0.21 & 0.16 & 0.66 & -66.5 & 75.1 \\
\hline Autumn & 1742 & 0.55 & 0.35 & 0.42 & 0.35 & 0.62 & 0.39 & -56.8 & 72.3 \\
\hline Winter & 1209 & 0.77 & 0.51 & 0.73 & 0.55 & 0.66 & 0.62 & -49.5 & 73.5 \\
\hline \multicolumn{10}{|c|}{ Ammonium } \\
\hline Annual & 5427 & 1.01 & 1.14 & 1.63 & 0.81 & 0.43 & 1.47 & 27.1 & 50.6 \\
\hline Spring & 1409 & 1.25 & 1.31 & 2.45 & 0.81 & 0.35 & 2.30 & 31.9 & 51.6 \\
\hline Summer & 1373 & 0.71 & 0.67 & 1.37 & 0.40 & 0.24 & 1.33 & 7.50 & 42.5 \\
\hline Autumn & 1287 & 0.80 & 1.11 & 0.81 & 0.75 & 0.59 & 0.77 & 39.7 & 56.0 \\
\hline Winter & 902 & 1.37 & 1.47 & 1.29 & 0.97 & 0.77 & 0.83 & 21.1 & 49.3 \\
\hline \multicolumn{10}{|c|}{ Total ammonia } \\
\hline Annual & 4036 & 1.49 & 1.55 & 1.29 & 1.06 & 0.60 & 1.07 & 6.00 & 43.7 \\
\hline Spring & 1036 & 1.66 & 1.91 & 1.30 & 1.26 & 0.58 & 1.20 & 14.3 & 43.2 \\
\hline Summer & 1027 & 1.50 & 1.30 & 1.30 & 0.84 & 0.58 & 1.08 & -10.7 & 35.9 \\
\hline Autumn & 1005 & 1.43 & 1.54 & 1.34 & 1.02 & 0.61 & 1.08 & 10.8 & 44.9 \\
\hline Winter & 629 & 1.47 & 1.41 & 1.28 & 0.96 & 0.69 & 0.93 & -1.80 & 48.2 \\
\hline
\end{tabular}


tions provided by LMDz-INCA overestimate the observed background concentrations during the autumn for the year 2009 (Chen et al., 2003; Szopa et al., 2009; Van Loon et al., 2007). The overestimation of $\mathrm{O}_{3}$ during the cold season is therefore attributed to the overestimation of the background concentrations at the boundaries of the domain.

\subsection{4 $\mathrm{PM}_{10}$ and $\mathrm{PM}_{2.5}$}

The model reproduces the temporal variability of $\mathrm{PM}_{10} \mathrm{ob}-$ servations throughout the year $(R=0.62$ and 0.56 , respectively) at both RB AirBase and EMEP stations. Interestingly, by contrast to the AirBase $\mathrm{RB}$ stations $(\mathrm{FB}=-5.5 \%)$, the $\mathrm{PM}_{10}$ concentrations are overestimated at EMEP RB stations $(\mathrm{FB}=2.90 \%)$. The lowest $\mathrm{FBs}$ are observed during autumn for AirBase $(\mathrm{FB}=0.30 \%)$ and summer for EMEP $(\mathrm{FB}=-2.30 \%)$, while the highest $\mathrm{FB}$ occurs during the winter for both networks (FB $=-20.30 \%$ for the AirBase and $-14.40 \%$ for EMEP sites). It should be noted that such differences in model performance point out that RB stations of EMEP and AirBase networks are characterized by a different representativeness, with the latter more influenced by local emissions. This is confirmed by comparing the statistics of the observed $\mathrm{PM}_{10}$ and $\mathrm{PM}_{2.5}$ data, with the observed mean and standard deviation at EMEP RB sites always lower than at AirBase RB sites.

At UB stations, the performance of the model for $\mathrm{PM}_{10}$ is good over the year $(\mathrm{FB}=-20.1 \%)$. The $\mathrm{FB}$ is lower during spring $(-12.2 \%)$ than in winter $(-36.6 \%)$ and $R$ is highest during the autumn (0.56) and lowest during summer and winter (0.47). Overall, using the AirBase network, the model agrees better, in terms of correlation at RB, than at UB sites ( 0.62 and 0.52 respectively) and more precisely during winter (0.67 and 0.47, respectively).

Throughout the year, the model correctly reproduces the temporal variation of the $\mathrm{PM}_{2.5}$ concentrations at both $\mathrm{RB}$ AirBase $(R=0.71)$ and EMEP $(R=0.68)$ sites and the highest correlation coefficient is observed during the winter (0.74 and 0.77 , respectively). Similar to $\mathrm{PM}_{10}$, at EMEP sites, the yearly mean FBs show that the model overestimates $\mathrm{PM}_{2.5}$ concentrations $(7.50 \%$ at AirBase and $8.6 \%$ at EMEP sites). The highest overestimation is observed during the autumn $(\mathrm{FB}=+14.2 \%$ at AirBase and $\mathrm{FB}=+15.7 \%$ at EMEP sites). However, during winter the model underestimates the RB concentrations $(-8.7 \%$ at AirBase and $-11.6 \%$ at EMEP sites).

At UB sites, the model captures the temporal variation throughout the year $(R=0.65)$ and the $\mathrm{FB}$ is rather low $(\mathrm{FB}=-6.4 \%)$. The highest $\mathrm{FB}$ is observed during the winter season $(-24.6 \%)$, while according to the RMSE $\left(5.94 \mu \mathrm{g} \mathrm{m}^{-3}\right)$, the best model performance takes place during the summer period, thus confirming the findings of Hodzic et al. (2005).

The intra-annual variability of model performances shows that CHIMERE has more difficulty in reproducing the PM concentration levels during winter, especially at the UB stations (RMSE $=34.88 \mu \mathrm{g} \mathrm{m}^{-3}$ for $\mathrm{PM}_{10}$ and $19.87 \mu \mathrm{g} \mathrm{m}^{-3}$ for $\mathrm{PM}_{2.5}$ ), when models generally are not able to correctly simulate the stable meteorological conditions that lead to high PM episodes (Stern et al., 2008). For both networks, CHIMERE performed better in reproducing the low $\mathrm{PM}_{10}$ concentrations as shown by the low quantiles indicated on the daily box-whisker plots time series (Figs. 5s and 6s). Moreover, the comparison of $\mathrm{PM}_{10}$ and $\mathrm{PM}_{2.5}$ model performance shows that the highest yearly mean correlation coefficient is calculated for $\mathrm{PM}_{2.5}$ at UB (0.65) and RB AirBase sites (0.71). This indicates that CHIMERE reproduces the temporal variability of $\mathrm{PM}_{2.5}$ across Europe better than the $\mathrm{PM}_{10}$ on a yearly basis. The better performance of the model for $\mathrm{PM}_{2.5}$ at $\mathrm{UB}$ stations confirms that the underestimation of $\mathrm{PM}_{10}$ is likely due to an underestimation of PM coarse, as reported in other studies (Nopmongcol et al., 2012; Kim et al., 2011; Matthias et al., 2008). The modelled concentration fields described in Sect. 3.1 show that sea salt and dust (coarse particles) can represent a significant part of the $\mathrm{PM}_{10}$ mass. Indeed, the dust in summer in south Spain and the sea salt during the winter over the North Sea, can reach, respectively, 90 and $80 \%$ of the $\mathrm{PM}_{10}$ masses. In these cases, the underestimation of PM coarse is reinforced in these parts of Europe. Conversely, the statistical indicators also show that the overestimation of $\mathrm{PM}_{2.5}$ is larger than that of $\mathrm{PM}_{10}$ at RB stations and is likely due to the corresponding overestimation of sulfate, the effect of which is less visible in the $\mathrm{PM}_{10}$ scores due to the compensating underestimation of the PM coarse.

$\mathrm{PM}_{2.5}$ and $\mathrm{PM}_{10}$ speciation data are available for several EMEP sites. In winter, as reported by Bessagnet et al. (2014) an important lack of organic compounds in models is responsible for large underestimate of models. As the model performance for $\mathrm{PM}_{10}$ is reflected by the quality of the reproduction of its different components, we also looked at the capacity of the model to reproduce three main inorganic $\mathrm{PM}_{10}$ compounds: sulfate, nitrate and ammonium.

\subsubsection{Sulfate}

Sulfuric acid is produced from the oxidation of sulfur oxides, and in turn forms sulfate particles. Secondary sulfate aerosol occurs predominantly in the accumulation mode (Altshuller, 1982) (diameter between 0.1 and $1.0 \mu \mathrm{m}$ ). Oxidant and $\mathrm{SO}_{2}$ availability are the limiting factors for sulfate formation. In 2009, the 37 stations available over Europe indicate that the highest concentrations of sulfate are measured during winter and spring. This tendency is reproduced by the model ( $R=0.57$ during spring and 0.52 during the winter) but some maxima are overestimated, especially during spring, autumn and winter. Consequently, the FB is rather low during summer $(\mathrm{FB}=20.1 \%)$ but indicates a large overestimation during spring $(\mathrm{FB}=53.7 \%)$. CHIMERE results are in contrast with the findings of CALIOPE (Pay et al., 2012a) and CMAQ 
(Matthias et al., 2008), which tend to underestimate the sulfate surface concentrations over Europe throughout the year.

The CHIMERE seasonal trend is in agreement with the study of Baker and Scheff (2007) over North America, but again in opposition with the results obtained by the CMAQ model over Spain (Pay et al., 2012a). In this case, the highest sulfate concentrations occur in summer due to high oxidation of $\mathrm{SO}_{2}$ during this period. A possible explanation of the CHIMERE overestimation can be inferred by looking at the remote station of Valentia (Ireland), where CHIMERE overestimates the observed yearly mean concentration by $0.40 \mu \mathrm{g} \mathrm{m}^{-3}$. The discrepancy detected at this station is comparable to yearly mean bias calculated at RB stations over the whole domain $\left(0.34 \mu \mathrm{g} \mathrm{m}^{-3}\right)$, thus suggesting that the general overestimation of sulfate can be related to the corresponding overestimation of the sulfate at the boundaries of the domain.

\subsubsection{Particulate and total nitrate}

Ammonia $\left(\mathrm{NH}_{3}\right)$ and nitric acid $\left(\mathrm{HNO}_{3}\right)$ are the two main gaseous precursors than can react together to form ammonium nitrate $\left(\mathrm{NH}_{4} \mathrm{NO}_{3}\right)$, depending on the temperature and the relative humidity ( $\mathrm{RH}$ ) (Ansari and Pandis, 1998). $\mathrm{HNO}_{3}$ can be produced through homogeneous reaction of $\mathrm{NO}_{2}$ with $\mathrm{OH}$ radical (daytime), reaction of $\mathrm{NO}_{3}$ with aldehydes or hydrocarbons (daytime) or hydrolysis of $\mathrm{N}_{2} \mathrm{O}_{5}$ in the troposphere (night time) (Richards, 1983; Russell et al., 1986). During the cold seasons (spring, autumn and winter), the equilibrium of the $\mathrm{NH}_{4} \mathrm{NO}_{3}$ system shifts towards the aerosol phase. At low $\mathrm{RH}, \mathrm{NH}_{4} \mathrm{NO}_{3}$ is solid but if $\mathrm{RH}$ overcomes the deliquescence threshold it turns to the aqueous phase $\left(\mathrm{NH}_{4}^{+}+\mathrm{NO}_{3}^{-}\right)$(Bauer et al., 2011).

Sulfuric acid plays a crucial role in the formation of nitrate and ammonium. Sulfate tends to react preferentially with $\mathrm{NH}_{3}$ to form $\left(\mathrm{NH}_{4}\right)_{2} \mathrm{SO}_{4}$. Two regimes can be identified: the ammonia poor and the ammonia rich regimes (Bauer et al., 2011). In the first case, there is not enough $\mathrm{NH}_{3}$ to neutralize the available sulfate. In the second case, sufficient ammonia is present to neutralize the sulfate and the remaining ammonia is available to react with nitrate to produce $\mathrm{NH}_{4} \mathrm{NO}_{3}$.

During cold periods, the formation of $\mathrm{NH}_{4} \mathrm{NO}_{3}$ is favoured and the associated low dispersive conditions enhance nitrate during these periods. Hence, the highest measured and modelled concentrations are observed during the winter period. The smallest FB is observed during this season $(-68.4 \%)$ and a rather high $R$ value $(0.67)$ is calculated, indicating that the temporal variability of nitrate concentrations is well reproduced by CHIMERE during this period. However, it is also shown that the nitrate is largely underestimated throughout the year $(\mathrm{FB}=-103.5 \%)$. Several explanations concerning the general underestimation of nitrate can be considered. First, the previously described overestimation of sulfate in poor ammonia regimes could contribute to the underestimation. Second, coarse nitrate chemistry is not repre- sented in the CHIMERE version used for the study, leading to an underestimation of the coarse mode nitrate aerosol. Typical reactions involved in the coarse nitrate chemistry include the neutralization of acidic aerosol particles $\left(\mathrm{NO}_{3}^{-}\right)$by different basic positive ions such as $\mathrm{Ca}^{2+}$ and $\mathrm{Mg}^{2+}$. $\mathrm{Na}^{+}$and $\mathrm{Cl}^{-}$are also involved along coastal areas, where high sea salt $(\mathrm{NaCl})$ concentrations are observed (Zhuang et al., 1999 and Kouyoumdjian and Saliba, 2006). A coarse nitrate formation scheme was implemented in CHIMERE as part of a research project by Hodzic et al. (2006), which showed that it can increase the nitrate model concentrations up to $3 \mu \mathrm{g} \mathrm{m}^{-3}$, especially in southern Europe, where coarse nitrates can represent the major part of the nitrate total mass. Hence, the introduction of a coarse nitrate formation scheme into CHIMERE could help reduce the bias between observed and modelled nitrate. Throughout the year, the total nitrate concentrations ( $R=0.56$ and $\mathrm{FB}=-55.1 \%)$ are much better reproduced than the nitrate alone $(R=0.28$ and $\mathrm{FB}=-103.5 \%)$. This result is consistent with the $\mathrm{NO}_{2}$ underestimation previously discussed, thus confirming a possible lack in $\mathrm{NO}_{\mathrm{x}}$ emissions. Finally, nitrate and total nitrate observed mean values are more similar than the corresponding modelled concentrations. This means that in the observations the equilibrium between $\mathrm{HNO}_{3}$ and nitrate is shifted more towards the aerosol phase than in the model. This is probably related to the higher availability of modelled sulfate (overestimated by CHIMERE), limiting the conversion of $\mathrm{HNO}_{3}$ into the aerosol phase, hence explaining the worsening in model performance when aerosol nitrate alone is considered.

\subsubsection{Particulate and total ammonia}

Along with sulfate, ammonium is the best SIA compound reproduced by CHIMERE. The FB shows a rather low overestimation throughout the year $(27.1 \%)$. The lowest FB is observed during the warm season $(7.5 \%)$. This overestimation is very likely driven by the corresponding overestimation of the sulfate. The highest $R$ index is calculated during winter $(0.77)$, indicating that the temporal variability of the ammonium concentrations are better reproduced in this season than during the rest of the year. A similar tendency is seen when using the CMAQ model over Spain and the UK (Pay et al., 2012b; Chemel et al., 2010).

Similarly, the total ammonia is also reproduced well by CHIMERE, with a very low bias observed during winter $(\mathrm{FB}=-1.8 \%)$. The performance degrades during summer, when the model underestimates observations $(\mathrm{FB}=$ $-10.7 \%)$. In contrast to the total nitrate, total ammonia is rather well reproduced throughout the year $(\mathrm{FB}=6.0 \%)$, suggesting that the yearly $\mathrm{NH}_{3}$ emissions are well estimated. However, the temporal profile of $\mathrm{NH}_{3}$ still needs to be improved. In that sense, recent work concerning the improvement of the temporal variability, as well as the magnitude and the spatial distribution of $\mathrm{NH}_{3}$ emissions from the agricultural sector, has been done for France (Hamaoui-Laguel 
et al., 2014). Unfortunately, a robust monthly time-profile for the $\mathrm{NH}_{3}$ emission from fertilizer is yet to be finalized for $\mathrm{Eu}$ rope (Menut and Bessagnet, 2010) before its implementation in the model.

\section{Summary and conclusions}

A high-resolution air quality CHIMERE simulation $(8 \mathrm{~km} \times 8 \mathrm{~km})$ over most of Europe was performed and evaluated for $\mathrm{SO}_{2}, \mathrm{NO}_{2}, \mathrm{O}_{3}, \mathrm{PM}_{10}, \mathrm{PM}_{2.5}$ and SIA using both RB and UB available stations for the year 2009. The model reproduces the temporal variability of $\mathrm{NO}_{2}$, $\mathrm{O}_{3}, \mathrm{PM}_{10}, \mathrm{PM}_{2.5}$ better at $\mathrm{RB}$ than at UB stations, with yearly correlation values for the different pollutants ranging between 0.62 and 0.77 at RB sites and between 0.52 and 0.73 at UB sites. Similarly, FBs show that the model performs slightly better at RB sites than at UB sites for $\mathrm{NO}_{2}(\mathrm{RB}=-33.9 \%, \mathrm{UB}=-53.6 \%), \mathrm{O}_{3}(\mathrm{RB}=20.10 \%$, $\mathrm{UB}=25.2 \%)$ and $\mathrm{PM}_{10}(\mathrm{RB}=-5.50 \%, \mathrm{UB}=-20.1)$.

The difficulty for the model in reproducing $\mathrm{NO}_{2}$ concentration is likely to be due to the general underestimation of $\mathrm{NO}_{\mathrm{x}}$ emissions, especially during the traffic daily peaks, as well as a horizontal resolution that is not high enough to represent correctly the spatial gradients of the emissions over medium and small cities. Moreover, $\mathrm{O}_{3}$ is overestimated, implying that $\mathrm{NO}_{\mathrm{x}}$ titration is not a limiting effect. The $\mathrm{NO}_{2}$ bias at UB sites is larger than at RB sites, so it can reasonably be assumed that $\mathrm{NO}_{\mathrm{x}}$ emissions are underestimated. Finally, the total nitrate bias is comparable to the $\mathrm{NO}_{2}$ bias, at least at UB stations, which represent about $70 \%$ of the available sites. This indicates that the chemical pathway of oxidized nitrogen from $\mathrm{NO}$ to $\mathrm{HNO}_{3}$ is correctly balanced with respect to observed values, suggesting that the limiting factor in nitrate production is the availability of $\mathrm{NO}_{2}$ and in turn of $\mathrm{NO}_{\mathrm{x}}$ emissions.

The overestimation of $\mathrm{O}_{3}$ by the model is related to the $\mathrm{NO}_{2}$ underestimation, as well as to the high $\mathrm{O}_{3}$ lateral boundary conditions concentrations, especially during the autumn season. Also, $\mathrm{PM}_{10}$ and $\mathrm{PM}_{2.5}$ show a less relevant underestimation than other pollutants, indicating that meteorology cannot be considered the only reason for model discrepancies.

At UB sites, CHIMERE performs better at reproducing the $\mathrm{PM}_{2.5}$ compared to the $\mathrm{PM}_{10}$. The degradation of model performance when moving from $\mathrm{PM}_{2.5}$ to $\mathrm{PM}_{10}$, which was also found in Pirovano et al. (2012), can surely be partially explained by uncertainties on SOA chemistry and their precursor emissions (Po valley and Mediterranean basin) as well as the underestimation of dust (south of Spain) and sea salt (western Europe) concentrations. However, the main reasons are likely to lie also in some missing or underestimated processes such as road dust resuspension (Amato et al., 2009), windblown dust (Yin et al., 2005; Park et al., 2010), especially over the Mediterranean area (Putaud et al., 2004), and finally PM coarse chemistry (e.g. nitrate), as discussed in Sect. 3.2.4.

Therefore, different areas of work have been identified and suggested as next steps to improve the model performance in the future:

- improvement of the CHIMERE urban parameterizations to better account for the urban effect on meteorology over medium and small cities,

- introduction of coarse nitrate chemistry and an advanced parameterization accounting for windblown dust emissions,

- continued development of national bottom-up emission inventories, as has been done for France (INS) and Spain (Baldasano et al., 2011), to merge them into the existing European emission inventory.

- continuous improvement on emission inventories to better account for semi-volatile organic compounds and their conversion to SOA, particularly for residential and traffic emissions.

Supplementary data associated with this paper can be found in the online version.

\section{The Supplement related to this article is available online at doi:10.5194/gmd-8-21-2015-supplement.}

Acknowledgements. The high-performance computing facility and staff at TGCC/CEA are gratefully acknowledged. This study was partly funded by the French Ministry in charge of Environment. This work was done under the auspices of the EC4MACS project of the Life Programme of the European Commission (LIFE06 ENV/AT/PREP/06). RSE's contribution to this work has been financed by the Research Fund for the Italian Electrical System under the Contract Agreement between RSE S.p.A. and the Italian Ministry of Economic Development - General Directorate for Nuclear Energy, Renewable Energy and Energy Efficiency in compliance with the Decree of March 8, 2006.

Edited by: A. Kerkweg

\section{References}

Altshuller, A. P.: Atmospheric concentrations and distributions of chemical substances, in: the Acidic Deposition Phenomenon and its Effects, US Environmental Protection Agency, Washington, DC, 1982.

Amann, M., Bertok, I., Borken-Kleefeld, J., Cofala, J., Heyes, C., Höglund-Isaksson, L., Klimont, Z., Nguyen, B., Posch, M., Rafaj, P., Sandler, R., Schöpp, W., Wagner, F., and Winiwarter, 
W.: Cost-effective control of air quality and greenhouse gases in Europe: Modeling and policy applications, Environ. Model. Softw., 26, 1489-1501, 2011.

Amato, F., Pandolfi, M., Escrig, A., Querol, X., Alastuey, A., Pey, J., Perez, N., and Hopke, P. K.: Quantifying road dust resuspension in urban environment by Multilinear Engine: A comparison with PMF2, Atmos. Environ., 43, 2770-2780, 2009.

Ansari, A. S. and Pandis, S. N.: Response of Inorganic PM to Precursor Concentrations, Environ. Sci. Technol., 32, 2706-2714, 1998.

Appel, K. W., Gilliam, R. C., Davis, N., and Zubrow, A.: Overview of the Atmospheric Model Evaluation Tool (AMET) v1.1 for evaluating meteorological and air quality models, Environ. Model. Softw., 26, 434-443, 2011.

Baldasano, J. M., Güereca, L. P., López, E., Gassó, S., and JimenezGuerrero, P.: Development of a high-resolution $(1 \mathrm{~km} \times 1 \mathrm{~km}$, 1h) emission model for Spain.: The High-Elective Resolution Modelling Emission System (HERMES), Atmos. Environ., 42, 7215-7233, 2011.

Balk, K., Kukkonen, J., Karatzas, K., Bassoukos, T., and Epitropou, V.: A European open access chemical weather forecasting portal, Atmos. Environ., 45, 6917-6922, 2011.

Baker, K. and Scheff, P.: Photochemical model performance for $\mathrm{PM}_{2.5}$ sulphate, nitrate, ammonium, and precursor species $\mathrm{SO}_{2}$, $\mathrm{HNO}_{3}$, and $\mathrm{NH}_{3}$ at background monitor locations in the Central and Eastern United States, Atmos. Environ., 41, 6185-6195, 2007.

Bauer, S. E., Koch, D., Unger, N., Metzger, S. M., Shindell, D. T., and Streets, D. G.: Nitrate aerosols today and in 2030: a global simulation including aerosols and tropospheric ozone, Atmos. Chem. Phys., 7, 5043-5059, doi:10.5194/acp-7-5043-2007, 2007.

Bessagnet, B., Menut, L., Curci, G., Hodzic, A., Guillaume, B., Liousse, C., Moukhtar, S., Pun, B., Seigneur, C., and Schulz, M.: Regional modeling of carbonaceous aerosols over Europe - Focus on Secondary Organic Aerosols, J. Atmos. Chem., 61, 175202, 2009.

Bessagnet, B., Seigneur, C., and Menut, L.: Impact of dry deposition of semi-volatile organic compounds on secondary organic aerosols, Atmos. Environ., 44, 1781, doi:10.1016/j.atmosenv.2010.01.027, 2010.

Bessagnet, B., Terrenoire, E., and Tognet, F.: EC4MACS Modelling Methodology: The CHIMERE Atmospheric Model, available at: http://www.ec4macs.eu/content/report/EC4MACS_ Publications/MR_Finalinpdf/Chimere_Methodologies_Final. pdf (last access: 28 November 2014), 2012.

Bessagnet, B., Colette, A., Meleux, F., Rouïl, L., Ung, A., Favez, O., Cuvelier, K., Thunis, P., Tsyro, S., Stern, R., Manders, A., Kranenburg, R., Aulinger, A., Bieser, J., Mircea, M., Briganti, G., Cappelletti, A., Calori, G., Finardi, S., Silibello, C., Ciarelli, G., Aksoyoglu, S., Prévot, A., Pay, M. T., Baldasano, M., García Vivanco, M., Garrido, J. L., Palomino, I., Martín, F., Pirovano, G., Roberts, P., Gonzalez, L.: The EURODELTA III exercise - Model evaluation with observations issued from the 2009 EMEP intensive period and standard measurements in Feb/Mar 2009, Technical EMEP report 1/2014, available at: http://emep.int/publ/reports/2014/MSCW_technical_1_2014. pdf (last access: 28 November 2014), 2014.
Bicheron, P., Amberg, V., Bourg, L., Petit, D., Huc, M., Miras, B., Brockmann, C., Delwart, S., Ranéra, F., Hagolle, O., Leroy, M., and Arino, O.: Geolocation assessment of 300m resolution MERIS GLOBCOVER ortho-rectified products, in: Proceedings of MERIS/AATSR Colloque, Frascati, 2008.

Bieser, J., Aulinger, A., Matthias, V., Quante, M., and Denier van der Gon, H. A. C.: Vertical emission profiles for Europe based on plume rise calculations, Environ. Pollut., 159, 2935-2946, doi:10.1016/j.envpol.2011.04.030, 2011.

Colette, A., Favez, O., Meleux, F., Chiappini, L., Haeffelin, M., Morille, Y., Malherbe, L., Papin, A., Bessagnet, B., Menut, L., Leoz, E., and Rouil, L.: Assessing in near real time the impact of the April 2010 Eyjafjallajokull ash plume on air quality, Atmos. Environ., 45, 1217-1221, 2011.

Colette, A., Bessagnet, B., Meleux, F., Terrenoire, E., and Rouïl, L.: Frontiers in air quality modelling, Geosci. Model Dev., 7, 203 210, doi:10.5194/gmd-7-203-2014, 2014.

Coll, I., Lasry, F., Fayet, S., Armengaud, A., and Vautard, R.: Simulation and evaluation of 2010 emission control scenarios in a Mediterranean area, Atmos. Environ., 43, 4194-4204, 2009.

Chemel, C., Sokhi, R. S., Yu, Y., Hayman, G. D., Vincent, K. J., Dore, A. J., Tang, Y. S., Prain, H. D., and Fisher, B.: Evaluation of a CMAQ simulation at high resolution over the UK for the calendar year 2003, Atmos. Environ., 44, 2927-2939, 2010.

Chen, K. S., Ho, Y. T., Lai, C. H., and Chou, Y.-M.: Photochemical modeling and analysis of meteorological parameters during ozone episodes in Kaohsiung, Taiwan, Atmos. Environ., 37, 1811-1823, 2003.

Denier van der Gon, H. A. C., Visschedijk, A., van der Brugh, H., and Dröge, R.: A high resolution European emission data base for the year 2005, A contribution to UBA-Project PAREST: Particle Reduction, Strategies, TNO-034-UT-2010-01895_RPT-ML, 2010.

Dennis, R., Fox, T., Fuentes, M., Gilliland, A., Hanna, S., Hogrefe, C., Irwin, J., Rao, S. T., Scheffe, R., Schere, K., Steyn, D., and Venkatram, A.: A framework for evaluating regional-scale numerical photochemical modeling systems, Environ. Fluid Mech, 10, 471-489, 2010.

EEA: Air quality in Europe - 2012 report, EEA Report No 4/2012, Office for Official Publications of the European Union, ISBN 978-92-9213-328-3, 2012.

Fisher, B., Kukkonen, J., Piringer, M., Rotach, M. W., and Schatzmann, M.: Meteorology applied to urban air pollution problems: concepts from COST 715, Atmos. Chem. Phys., 6, 555-564, doi:10.5194/acp-6-555-2006, 2006.

Flaounas, E., Coll, I., Armengaud, A., and Schmechtig, C.: The representation of dust transport and missing urban sources as major issues for the simulation of PM episodes in a Mediterranean area, Atmos. Chem. Phys., 9, 8091-8101, doi:10.5194/acp-9-80912009, 2009.

Fountoukis, C., Koraj, D., Denier van der Gon, H. A. C., Charalampidis, P. E., Pilinis, C., and Pandis, S. N.: Impact of grid resolution on the predicted fine PM by a regional 3D chemical transport model, Atmos. Environ., 68, 24-32, doi:10.1016/j.atmosenv.2012.11.008, 2013.

Ginoux, P., Chin, M., Tegen, I., Prospero, J. M., Holben, B., Dubovik, O., and Lin, S.-J.: Sources and distributions of dust aerosols simulated with the GOCART model, J. Geophys. Res., 106, 20255-20273, 2001. 
Guenther, A., Karl, T., Harley, P., Wiedinmyer, C., Palmer, P. I., and Geron, C.: Estimates of global terrestrial isoprene emissions using MEGAN (Model of Emissions of Gases and Aerosols from Nature), Atmos. Chem. Phys., 6, 3181-3210, doi:10.5194/acp-63181-2006, 2006.

Hamaoui-Laguel, L., Meleux, F., Beekmann, M., Bessagnet, B., Génermont, S., Cellier, P., and Létinois, L.: Improving ammonia emissions in air quality modelling for France, Atmos. Environ., 94, 584-595, doi:10.1016/j.atmosenv.2012.08.002, 2014.

Hauglustaine, D. A., Hourdin, F., Jourdain, L., Filiberti, M.A., Walters, S., Lamarque, J.-F., and Holland, E. A.: Interactive chemistry in the Laboratoire de Meteorologie Dynamique general circulation model: Description and background tropospheric chemistry evaluation, J. Geophys. Res., 109, D04314, doi:10.1029/2003JD003957, 2004.

Hodzic, A., Jimenez, J. L., Madronich, S., Canagaratna, M. R., DeCarlo, P. F., Kleinman, L., and Fast, J.: Modeling organic aerosols in a megacity: potential contribution of semi-volatile and intermediate volatility primary organic compounds to secondary organic aerosol formation, Atmos. Chem. Phys., 10, 5491-5514, doi:10.5194/acp-10-5491-2010, 2010.

Hodzic, A., Bessagnet, B., and Vautard, R.: A model evaluation of coarse-mode nitrate heterogeneous formation on dust particle, Atmos. Environ., 40, 4158-4171, 2006.

Hodzic, A., Vautard, R., Bessagnet, B., Lattuati, M., and Moreto, F.: On the quality of long-term urban particulate matter simulation with the CHIMERE model, Atmos. Environ., 39, 58515864, 2005.

Jimenez, P. A. and Dudhia, J.: Improving the representation of resolved and unresolved topographic effects on surface wind in the WRF model, J. Appl. Meteor. Climatol., 51, 300-316, 2012.

Jiménez-Guerrero, P., Jorba, O., Pay, M. T., Montávez, J. P., Jerez, S., Gómez-Navarro, J. J., and Baldasano, J. M.: Comparison of two different sea-salt aerosol schemes as implemented in air quality models applied to the Mediterranean Basin, Atmos. Chem. Phys., 11, 4833-4850, doi:10.5194/acp-11-4833-2011, 2011.

Kaiser, J. W., Heil, A., Andreae, M. O., Benedetti, A., Chubarova, N., Jones, L., Morcrette, J.-J., Razinger, M., Schultz, M. G., Suttie, M., and van der Werf, G. R.: Biomass burning emissions estimated with a global fire assimilation system based on observed fire radiative power, Biogeosciences, 9, 527-554, doi:10.5194/bg-9-527-2012, 2012.

Kiesewetter, G., Borken-Kleefeld, J., Schöpp, W., Heyes, C., Thunis, P., Bessagnet, B., Terrenoire, E., Gsella, A., and Amann, M.: Modelling $\mathrm{NO}_{2}$ concentrations at the street level in the GAINS integrated assessment model: projections under current legislation, Atmos. Chem. Phys., 14, 813-829, doi:10.5194/acp-14813-2014, 2014.

Kim, Y., Sartelet, K., and Seigneur, C.: Formation of secondary aerosols over Europe: comparison of two gas-phase chemical mechanisms, Atmos. Chem. Phys., 11, 583-598, doi:10.5194/acp-11-583-2011, 2011.

Kouyoumdjian, H. and Saliba, N. A.: Mass concentration and ion composition of coarse and fine particles in an urban area in Beirut: effect of calcium carbonate on the absorption of nitric and sulfuric acids and the depletion of chloride, Atmos. Chem. Phys., 6, 1865-1877, doi:10.5194/acp-6-1865-2006, 2006.
Kuenen, J., Denier van der Gon, H., Visschedijk, A., van der Burgh, H., and van Gijlswijk, R.: MACC European emission inventory 2003-2007, TNO, 2011.

Kukkonen, J., Olsson, T., Schultz, D. M., Baklanov, A., Klein, T., Miranda, A. I., Monteiro, A., Hirtl, M., Tarvainen, V., Boy, M., Peuch, V.-H., Poupkou, A., Kioutsioukis, I., Finardi, S., Sofiev, M., Sokhi, R., Lehtinen, K. E. J., Karatzas, K., San José, R., Astitha, M., Kallos, G., Schaap, M., Reimer, E., Jakobs, H., and Eben, K.: A review of operational, regional-scale, chemical weather forecasting models in Europe, Atmos. Chem. Phys., 12, 1-87, doi:10.5194/acp-12-1-2012, 2012.

Mass, C. F. and Ovens, D.: Fixing WRF's high speed wind bias: a new subgrid scale drag parameterization and the role of detailed verification, 91st AMS Annual Meeting, Seattle, WA, available at: http://ams.confex.com/ams/91Annual/webprogram/ Paper180011.html (last access: 3 November 2011), 2011.

Matthias, V.: The aerosol distribution in Europe derived with the Community Multiscale Air Quality (CMAQ) model: comparison to near surface in situ and sunphotometer measurements, Atmos. Chem. Phys., 8, 5077-5097, doi:10.5194/acp-8-5077-2008, 2008.

Matthias, V., Aulinger, A., Bieser, J., Cuesta, J., Geyer, B., Langmann, B., Serikov, I., Mattis, I., Minikin, A., Mona, L., Quante, M., Schumann, U., Weinzierl, B.: The ash dispersion over Europe during the Eyjafjallajökull eruption - Comparison of MAQ simulations to remote sensing and air-borne in-situ observations, Atmospheric Environment, 48, 184-194, doi:10.16/j.atmosenv.2011.06.077, 2012.

Menut, L. and Bessagnet, B.: Atmospheric composition forecasting in Europe, Ann. Geophys., 28, 61-74, doi:10.5194/angeo-28-612010, 2010.

Menut, L., Bessagnet, B., Khvorostyanov, D., Beekmann, M., Blond, N., Colette, A., Coll, I., Curci, G., Foret, G., Hodzic, A., Mailler, S., Meleux, F., Monge, J.-L., Pison, I., Siour, G., Turquety, S., Valari, M., Vautard, R., and Vivanco, M. G.: CHIMERE 2013: a model for regional atmospheric composition modelling, Geosci. Model Dev., 6, 981-1028, doi:10.5194/gmd6-981-2013, 2013.

Middleton, P., Stockwell, W. R., and Carter, W. P.: Agregation and analysis of volatile organic compound emissions for regional modeling, Atmos. Environ., 24, 1107-1133, 1990.

Miglietta, M., Thunis, P., Georgieva, E., Pederzoli, A., Bessagnet, B., Terrenoire, E., and Colette, A.: Evaluation of WRF model performance in different European regions with the delta- Fairmode evaluation tool, Int. J. Environ. Pollut., 50, 83-97, 2012.

Nenes, A., Pilinis, C., and Pandis, S.: ISORROPIA: A new thermodynamic model for inorganic multicomponent atmospheric aerosols, Aquatic Geochem., 4, 123-152, 1998.

Nopmongcol, U., Koo, B., Tai, E., Jung, J., Piyachaturawat, P., and Sportisse, B.: Modeling Europe with CAMx for the air quality model evaluation international initiative (AQMEII), Atmos. Environ., 53, 60-74, 2012.

Park, S. H., Gong, S. L., Gong, W., Makar, P. A., Moran, M. D., Zhang, J., and Stroud, C. A.: Relative impact of windblown dust versus anthropogenic fugitive dust in $\mathrm{PM}_{2.5}$ on air quality in North America, J. Geophys. Res., 115, D16210, doi:10.1029/2009JD013144, 2010.

Pay, M. T., Piot, M., Jorba, O., Gassó, S., Gonçalves, M., Basart, S., Dabdub, D., Jiménez-Guerrero, P., and Baldasano, J. M.: A full 
year evaluation of the CALIOPE-EU air quality modeling system over Europe for 2004, Atmos. Environ., 44, 3322-3342, 2010.

Pay, M. T., Jiménez-Guerrero, P., and Baldasano, J. M.: Assessing sensitivity regimes of secondary inorganic aerosol formation in Europe with the CALIOPE-EU modeling system, Atmos. Environ., 51, 146-164, 2012a.

Pay, M. T., Jiménez-Guerrero, P., Jorba, O., Basart, S., Querol, X., Pandolfi, M., and Baldasano, J. M.: Spatio-temporal variability of concentrations and speciation of particulate matter across Spain in the caliope modeling system, Atmos. Environ., 46, 376-396, 2012b.

Pirovano, G., Balzarini, A., Bessagnet, B., Emery, C., Kallos, G., Meleux, F., Mitsakou, C., Nopmongcol, U., Riva, G M., and Yarwood, G.: Investigating impacts of chemistry and transport model formulation on model performance at European scale, Atmos. Environ., 53, 93-109, 2012.

Putaud, J.-P., Raes, F., Dingenen, Van, Bruggemann, E., Facchini, E-C., Decesari, S., Fuzzi, S., Gehrig, R., Hüglin, C., Laj, P., Lorbeer, G., Maenhaut, W., Mihalopoulos, N., Müller, K., Querol, X., Rodriguez, S., Schneider, J., Spindler, G., ten Brink, H., Tørseth, K., and Wiedensohler, A.: A European aerosol phenomenology e 2: chemical characteristics of particulate matter at kerbside, urban, rural and background sites in Europe, Atmos. Environ., 38, 2579-2595, 2004.

Quayle, R. G and Diaz, H. F.: Heating Degree Day Data Applied to Residential Heating Energy Consumption, J. Appl. Meteor., 19, 241-246, 1980.

Queen, A. and Zhang, Y.: Examining the sensitivity of MM5CMAQ predictions to explicit microphysics schemes and horizontal grid resolutions, Part III - The impact of horizontal grid resolution, Atmos. Environ., 42, 3869-3881, 2008.

Richards, L. W.: Comments on the oxidation of $\mathrm{NO}_{2}$ to nitrate: day and night, Atmos. Environ., 17, 397-402, 1983.

Russell, A. G., Cass, G. R., and Seinfeld, J. H.: On some aspects of night-time atmospheric chemistry, Environ. Sci. Technol., 20, 1167-1172, 1986.

Sarrat, C., Lemonsu, A., Masson, V., and Guedalia, D.: Impact of urban heat island on regional atmospheric pollution, Atmos. Environ., 40, 1743-1758, 2006.

Schmidt, H., Derognat, C., Vautard, R., and Beekmann, M. : A comparison of simulated and observed ozone mixing ratios for the summer of 1998 in western Europe, Atmos. Environ., 35, 62776297, 2001.

Society, E. I.: Generation of European Emission Data for Episodes (GENEMIS) project, EUROTRAC annual report 1993, part 5. Technical report, EUROTRAC, Garmish-Partenkirchen, Germany, 1994

Solazzo, E., Di Sabatino, S., Aquilina, N., Dudek, A., and Britter, R.: Coupling Mesoscale Modelling with a Simple Urban Model: The Lisbon Case Study, Bound.-Lay. Meteorol., 137, 441-457, doi:10.1007/s10546-010-9536-6, 2010.

Solazzo, E., Bianconi, R., Pirovano, G., Matthias, V., Vautard, R., Moran, M. D., Appel, K. W., Bessagnet, B., Brandt, J., Christensen, J. H., Chemel, C., Coll, I., Ferreira, J., Forkel, R., Francis, X. V., Grell, G., Grossi, P., Hansen, A. B., Miranda, A. I., Nopmongcol, U., Prank, M., Sartelet, K. N., Schaap, M., Silver, J. D., Sokhi, R. S., Vira, J., Werhahn, J., Wolke, R., Yarwood, G., Zhang, J., Trivikrama Rao, S., and Galmarini, S.: Operational model evaluation for particulate matter in Europe and North
America in the context of AQMEII, Atmos. Environ., 53, 75-92, 2012.

Stern, R., Builtjes, P., Schaap, M., Timmermans, T., Vautard, R., Hodzic, A., Memmesheimer, M., Feldmann, H., Renner, E., Wolke, R., and Kerschbaumer, A.: A model inter-comparison study focusing on episodes with elevated $\mathrm{PM}_{10}$ concentrations, Atmos. Environ., 42, 4567-4588, 2008.

Stroud, C. A., Makar, P. A., Moran, M. D., Gong, W., Gong, S., Zhang, J., Hayden, K., Mihele, C., Brook, J. R., Abbatt, J. P. D., and Slowik, J. G.: Impact of model grid spacing on regionaland urban- scale air quality predictions of organic aerosol, Atmos. Chem. Phys., 11, 3107-3118, doi:10.5194/acp-11-31072011, 2011.

Szopa, S., Foret, G., Menut, L., and Cozic, A.: Impact of large scale circulation on European summer surface ozone and consequences for modelling forecast, Atmos. Environ., 43, 11891195, 2009.

Tarrason, L., Fagerli, H., Klein, H., Simpson, D., Benedictow, A. Vestreng, V., Rigler, E., Emberson, L., Posch, M., and Spranger, T.: Transboundary acidification, eutrophication and ground level ozone in Europe since 1990 to 2004, EMEP Status Report 2006 to support the Review of Gothenburg Protocol Joint MSC/W \& CCC \& ICP-FORESTs \& ICP-M\&M \& ETC/ACC Report. Oslo, Norway: Norwegian Meteorological Institute, 2006.

Thunis, P., Georgieva, E., and Pederzoli, A.: A tool to evaluate air quality model performances in regulatory applications, Environ. Model. Softw., 38, 220-230, doi:10.1016/j.envsoft.2012.06.005, 2012.

Timmermans, R. M. A., Denier van der Gon, H. A. C., Kuenen, J. J. P., Segers, A. J., Honoré, C., Perrussel, O., Builtjes, P. J. H., and Schaap, M.: Quantification of the urban air pollution increment and its dependency on the use of down-scaled and bottom-up city emission inventories, Urban Climate, 6, 44-62, 2012.

Tombette, M. and Sportisse, B.: Aerosol modeling at a regional scale.: Model-to-data comparison and sensitivity analysis over Greater Paris, Atmos. Environ., 41, 6941-6950, 2007.

Troen, I. and Mahrt, L.: A simple model of the atmospheric boundary layer: Sensitivity to surface evaporation, Bound.-Layer Meteorol., 37, 129-148, 1986.

Van Loon, M., Vautard, R., Schaap, M., Bergström, R., Bessagnet, B., Brandt, J., Builtjes, P. J. H., Christensen, J. H., Cuvelier, C., Graff, A., Jonson, J. E., Krol, M., Langner, J., Roberts, P., Rouil, L., Stern, R., Tarrasón, L., Thunis, P., Vignati, E., and Whit., L.: Wind evaluation of long-term ozone simulations from seven regional air quality models and their ensemble, Atmos. Environ., 41, 2083-2097, 2007.

Vautard, R., Bessagnet, B., Chin, M., and Menut, L.: On the contribution of natural Aeolian sources to particulate matter concentrations in Europe: testing hypotheses with a modelling approach, Atmos. Environ., 39, 3291-3303, 2005.

Vautard, R., Builtjes, P. H. J., Thunis, P., Cuvelier, K., Bedogni, M., Bessagnet, B., Honore C., Moussiopoulos, N., Pirovano, G., Schaap, M., Stern, R., Tarrason, L., and Van Loon, M.: Evaluation and intercomparison of Ozone and $\mathrm{PM}_{10}$ simulations by several chemistry-transport models over 4 European cities within the CityDelta project, Atmos. Environ., 41, 173-188, 2007a.

Vautard, R., Maidi, M., Menut, L., Beekmann, M., and Colette, A.: Boundary layer photochemistry simulated with a two-stream convection scheme, Atmos. Environ., 41, 8275-8287, $2007 \mathrm{~b}$. 
Vautard, R., Moran, M. D., Solazzo, E., Gilliam, R. C., Matthias, V., Bianconi, R., Chemel, C., Ferreira, J., Geyer, B., Hansen, A. B., Jericevic, A., Prank, M., Segers, A., Silver, J. D., Werhahn, J., Wolke, R., Rao, S. T., and Galmarini, S.: Evaluation of the meteorological forcing used for the Air Quality Model Evaluation International Initiative (AQMEII) air quality simulations, Atmos. Environ., 53, 15-37, 2012.

Verbai, Z., Lakatos, Á., and Kalmár, F.: Prediction of energy demand for heating of residential buildings using variable degree day, Energy, 76, 780-787, 2014.

Vestreng, V.: Review and revision of emission data reported to CLRTAP, EMEP Status report, 2003.

Vestreng, V., Myhre, G., Fagerli, H., Reis, S., and Tarrasón, L.: Twenty-five years of continuous sulphur dioxide emission reduction in Europe, Atmos. Chem. Phys., 7, 3663-3681, doi:10.5194/acp-7-3663-2007, 2007.
Wolke, R., Schröder, W., Schrödner, R., and Renner, E.: Influence of grid resolution and meteorological forcing on simulated European air quality.: A sensitivity study with the modeling system COSMO-MUSCAT, Atmos. Environ., 53, 110-130, doi:10.1016/j.atmosenv.2012.02.085, 2012.

Yin, D., Nickovic, S., Barbaris, B., Candy, B., and Sprigg, W. A.: Modeling wind-blown desert dust in the southwestern United States for public health warning: a case study, Atmos. Environ., 39, 6243-6254, 2005.

Zhang, Y., Sartelet, K., Zhu, S., Wang, W., Wu, S.-Y., Zhang, X., Wang, K., Tran, P., Seigneur, C., and Wang, Z.-F.: Application of WRF/Chem-MADRID and WRF/Polyphemus in Europe - Part 2: Evaluation of chemical concentrations and sensitivity simulations, Atmos. Chem. Phys., 13, 6845-6875, doi:10.5194/acp-136845-2013, 2013.

Zhuang, H., Chan, C. K., Fang, M., and Wexler, A. S.: Formation of nitrate and non-sea-salt sulfate on coarse particles, Atmos. Environ., 33, 4223-4233, 1999. 